\title{
Review Article \\ Bacteria in Nanoparticle Synthesis: Current Status and Future Prospects
}

\author{
Siavash Iravani \\ Biotechnology Department, Faculty of Pharmacy and Pharmaceutical Sciences, Isfahan University of Medical Sciences, \\ Isfahan 81744-176, Iran \\ Correspondence should be addressed to Siavash Iravani; siavashira@gmail.com
}

Received 26 March 2014; Revised 9 July 2014; Accepted 4 August 2014; Published 29 October 2014

Academic Editor: Matthias Labrenz

Copyright (C) 2014 Siavash Iravani. This is an open access article distributed under the Creative Commons Attribution License, which permits unrestricted use, distribution, and reproduction in any medium, provided the original work is properly cited.

\begin{abstract}
Microbial metal reduction can be a strategy for remediation of metal contaminations and wastes. Bacteria are capable of mobilization and immobilization of metals and in some cases, the bacteria which can reduce metal ions show the ability to precipitate metals at nanometer scale. Biosynthesis of nanoparticles (NPs) using bacteria has emerged as rapidly developing research area in green nanotechnology across the globe with various biological entities being employed in synthesis of NPs constantly forming an impute alternative for conventional chemical and physical methods. Optimization of the processes can result in synthesis of NPs with desired morphologies and controlled sizes, fast and clean. The aim of this review is, therefore, to make a reflection on the current state and future prospects and especially the possibilities and limitations of the above mentioned bio-based technique for industries.
\end{abstract}

\section{Introduction}

Nanoscience and nanotechnology has attracted a great interest over the last few years due to its potential impact on many scientific areas such as energy, medicine, pharmaceutical industries, electronics, and space industries. This technology deals with small structures and small-sized materials of dimensions in the range of few nanometers to less than 100 nanometers. Nanoparticles (NPs) show unique and considerably changed chemical, physical, and biological properties compared to bulk of the same chemical composition, due to their high surface-to-volume ratio. NPs exhibit size and shape-dependent properties which are of interest for applications ranging from biosensing and catalysts to optics, antimicrobial activity, computer transistors, electrometers, chemical sensors, and wireless electronic logic and memory schemes. These particles also have many applications in different fields such as medical imaging, nanocomposites, filters, drug delivery, and hyperthermia of tumors [1-4].

An important area of research in nanoscience deals with the synthesis of nanometer-size particles of different morphologies, sizes, and monodispersity [5]. In this regard, there is a growing need to develop reliable, nontoxic, clean, ecofriendly, and green experimental protocols for the synthesis of NPs [6-12]. One of the options to achieve this objective is to use natural processes such as use of enzymes, microbial enzymes, vitamins, polysaccharides, biodegradable polymers, microorganisms, and biological systems for synthesis of NPs. One approach that shows immense potential is based on the biosynthesis of NPs using bacteria (a kind of bottom up approach) $[6,7,11]$. The objects of recent studies tend to provide a controlled and up-scalable process for biosynthesis of monodispersed and highly stableNPs. Thus, a wide number of bacterial species have been used in green nanotechnology to research alternative methods for the synthesis of NPs. Researchers have started to use biomass or cell extracts of bacteria for synthesizing NPs. Bacteria are considered as a potential biofactory for the synthesis of NPs like gold, silver, platinum, palladium, titanium, titanium dioxide, magnetite, cadmium sulphide, and so forth. Some well-known examples of bacteria synthesizing inorganic materials include magnetotactic bacteria and S layer bacteria. Most metal ions are toxic for bacteria, and, therefore, the bioreduction of ions or the formation of water insoluble complexes is a defense mechanism developed by the bacteria to overcome such toxicity [13-16]. In this review, most of the 
bacteria used in nanoparticle biosynthesis are shown. The aim of this paper is, therefore, to make a reflection on the current state and future prospects and especially the possibilities and limitations of the above mentioned bio-based technique for industries.

\section{Bacteria in Nanoparticle Synthesis}

Bacteriapossess remarkable ability to reduce heavy metal ions and are one of the best candidates for nanoparticle synthesis. For instance, some bacterial species have developed the ability to resort to specific defense mechanisms to quell stresses like toxicity of heavy metal ions or metals. It was observed that some of them could survive and grow even at high metal ion concentrations (e.g., Pseudomonas stutzeri and Pseudomonas aeruginosa) $[47,55]$. Moreover, Brock and Gustafson [56] reported that Thiobacillus ferrooxidans, $T$. thiooxidans, and Sulfolobus acidocaldarius were able to reduce ferric ion to the ferrous state when growing on elemental sulfur as an energy source. T. thiooxidans was able to reduce ferric iron at low $\mathrm{pH}$ medium aerobically. The ferrous iron formed was stable to autoxidation and $T$. thiooxidans was unable to oxidize ferrous iron, but the bioreduction of ferric iron using T. ferrooxidans was not aerobic because of the rapid bacterial reoxidation of the ferrous iron in the presence of oxygen [56]. Other biomineralization phenomena, such as the formation of tellurium (Te) in Escherichia coli $\mathrm{K} 12$ [57], the direct enzymatic reduction of Tc (VII) by resting cells of Shewanella (previously Alteromonas) putrefaciens and Geobacter metallireducens (previously known as strain GS-15) [58] and the reduction of selenite to selenium by Enterobacter cloacae, Desulfovibrio desulfuricans, and Rhodospirillum rubrum [26] have been reported, as well. Mullen et al. [14] examined the ability of Bacillus cereus, B. subtilis, E. coli, and $P$. aeruginosa for removing $\mathrm{Ag}^{+}, \mathrm{Cd}^{2+}, \mathrm{Cu}^{2+}$, and $\mathrm{La}^{3+}$ from solution. They found that bacterial cells were capable of binding large quantities of metallic cations. Moreover, some of these bacteria are able to synthesize inorganic materials like the magnetotactic bacteria, which synthesize intracellular magnetite NPs [53]. In this section, most of the bacterial species used in nanoparticle biosynthesis are shown (Table 1).

2.1. Silver NPs. Saifuddin et al. [22] have described a novel combinational synthesis approach for green biosynthesis of silver NPs using a combination of culture supernatant of Bacillus subtilis and microwave irradiation in water. They reported the extracellular biosynthesis of monodispersed silver NPs $(\sim 5-50 \mathrm{~nm})$ using supernatants of B. subtilis, but in order to increase the rate of reaction and reduce the aggregation of the produced NPs, they used microwave radiation which might provide uniform heating around the NPs and could assist the digestive ripening of particles with no aggregation [22]. Kalishwaralal et al. [59] reported extracellular synthesis of silver NPs $(\sim 40 \mathrm{~nm})$ by bioreduction of aqueous $\mathrm{Ag}^{+}$ions with the culture supernatant of Bacillus licheniformis. Moreover, well-dispersed silver nanocrystals $(\sim 50 \mathrm{~nm})$ were synthesized using B. licheniformis [60]. In case of Bacillus flexus, spherical and triangular shaped silver NPs
( 12-65 nm) were successfully biosynthesized. The NPs were stable in aqueous solution in five-month period of storage at room temperature in the dark. These NPs showed efficacy on antibacterial property against clinically isolated multidrug resistant (MDR) microorganisms [61]. Wei et al. [62] reported the synthesis of circular and triangular crystalline silver NPs $(\sim 14.6 \mathrm{~nm})$ by solar irradiation of cell-free extracts of Bacillus amyloliquefaciens and silver nitrate $\left(\mathrm{AgNO}_{3}\right)$. Light intensity, extract concentration, and $\mathrm{NaCl}$ addition influenced the synthesis of silver NPs. Under optimized conditions (solar intensity 70,000 lx, extract concentration $3 \mathrm{mg} / \mathrm{mL}$, and $\mathrm{NaCl}$ content $2 \mathrm{mM}), 98.23 \pm 0.06 \%$ of the $\mathrm{Ag}^{+}(1 \mathrm{mM})$ was reduced to silver NPs within $80 \mathrm{~min}$. Since heat-inactivated extracts also mediated the formation of silver NPs, enzymatic reactions are likely not involved in silver NPs formation. The produced NPs showed antimicrobial activity against B. subtilis and Escherichia coli in liquid and solid medium [62]. Furthermore, Bacillus cereus isolated from the Garcinia xanthochymus was used for green biosynthesis of silver NPs ( 20-40 nm) [18]. The produced NPs showed antibacterial activity against pathogenic bacteria like E. coli, Pseudomonas aeruginosa, Salmonella typhi, and Klebsiella pneumoniae.

Pseudomonas stutzeri AG259, the silver-resistant bacterial strain, isolated from a silver mine, intracellularly accumulated silver NPs along with some silver sulfide ranging in size from 35 to $46 \mathrm{~nm}$ [63]. Larger particles were formed when P. stutzeri AG259 challenged high concentrations of silver ions during culturing, resulting in intracellular formation of silver NPs ranging in size from a few $\mathrm{nm}$ to $200 \mathrm{~nm}$ $[13,64]$. P. stutzeri AG259 detoxificated silver through its precipitation in the periplasmic space and its bioreduction to elemental silver with a variety of crystal typologies, such as hexagons and equilateral triangles, as well as three different types of particles: elemental crystalline silver, monoclinic silver sulfide acanthite $\left(\mathrm{Ag}_{2} \mathrm{~S}\right)$, and a further undetermined structure [64]. The periplasmic space limited the thickness of the crystals but not their width, which could be rather large ( 100-200 nm) [13].

Cell-free culture supernatants of five psychrophilic bacteria Phaeocystis antarctica, Pseudomonas proteolytica, Pseudomonas meridiana, Arthrobacter kerguelensis, and Arthrobacter gangotriensis and two mesophilic bacteria Bacillus indicus and Bacillus cecembensis have been used to biosynthesize silver NPs $(\sim 6-13 \mathrm{~nm})$. These NPs were stable for 8 months in the dark. The synthesis and stability of silver NPs appeared to depend on the temperature, $\mathrm{pH}$, or the species of bacteria from which the supernatant was used. It was observed that the A. kerguelensis supernatant could not produce silver NPs at the temperature where $P$. antarctica could synthesize silver NPs. Therefore, this study provided important evidence that the factors in the cell-free culture supernatants which facilitated the synthesis of silver NPs varied from bacterial species to species [65].

Our research group demonstrated the green biosynthesis of silver NPs using Lactobacillus casei subsp. casei at room temperature [12] (Figure 1). Previous researchers reported qualitative synthesis of silver NPs by Lactobacillus sp., but they did not optimize the reaction mixture. The biosynthesized NPs were almost spherical, single $(\sim 25-50 \mathrm{~nm})$, or in 
TABLE 1: Green biosynthesis of NPs using bacteria.

\begin{tabular}{|c|c|c|c|c|}
\hline Bacteria & Nanoparticle & Size $(\mathrm{nm})$ & Morphology & References \\
\hline Aeromonas sp. SH10 & Silver & 6.4 & - & {$[17]$} \\
\hline Bacillus cereus & Silver & $20-40$ & Spherical & {$[18]$} \\
\hline Bacillus megatherium D01 & Gold & $1.9 \pm 0.8$ & Spherical & {$[19]$} \\
\hline Bacillus subtilis 168 & Gold & $5-25$ & Octahedral & {$[20,21]$} \\
\hline Bacillus subtilis & Silver & $5-50$ & Spherical and triangular & {$[22]$} \\
\hline Clostridium thermoaceticum & Cadmium sulfide & - & Amorphous & {$[23]$} \\
\hline Corynebacterium sp. SH09 & Silver & $10-15$ & - & {$[24]$} \\
\hline Desulfobacteraceae & Zinc sulfide & $2-5$ & Spherical & {$[25]$} \\
\hline Desulfovibrio desulfuricans & Palladium and selenium & - & - & {$[26,27]$} \\
\hline Desulfovibrio vulgaris & $\begin{array}{l}\text { Gold, uranium, and } \\
\text { chromium }\end{array}$ & - & - & {$[28]$} \\
\hline $\begin{array}{l}\text { Desulfovibrio magneticus } \\
\text { strain RS-1 }\end{array}$ & Magnetite & Up to 30 & Crystalline & {$[29]$} \\
\hline Enterobacter cloacae & Silver and selenium & - & - & {$[26]$} \\
\hline Escherichia coli & Cadmium sulfide & $2-5$ & Wurtzite crystal & {$[30]$} \\
\hline Escherichia coli & Silver & $8-9$ & Spherical & {$[31]$} \\
\hline Escherichia coli DH5 $\alpha$ & Silver & $10-100$ & Spherical & {$[32]$} \\
\hline Escherichia coli DH5 $\alpha$ & Gold & $25 \pm 8$ & $\begin{array}{l}\text { Spherical, triangular, and } \\
\text { quasi-hexagonal }\end{array}$ & {$[33]$} \\
\hline Escherichia coli MC4100 & Gold & Less than 10 to 50 & $\begin{array}{l}\text { Spherical, triangular, hexagonal, and } \\
\text { rod shape }\end{array}$ & {$[34]$} \\
\hline Geobacillus sp. & Gold & $5-50$ & Quasi-hexagonal & {$[35]$} \\
\hline Geovibrio ferrireducens & Gold & - & - & {$[28]$} \\
\hline Klebsiella aerogenes & Cadmium sulfide & $20-200$ & Crystalline & {$[36]$} \\
\hline Klebsiella pneumonia & Silver & $\begin{array}{l}28.2-122 \\
\text { (average size of } \\
52.2 \text { ) }\end{array}$ & Spherical & {$[37]$} \\
\hline Lactobacillus strains & Gold & $\begin{array}{l}20-50 \text { and above } \\
100\end{array}$ & $\begin{array}{l}\text { Crystalline, hexagonal, triangular, and } \\
\text { cluster }\end{array}$ & {$[38]$} \\
\hline Lactobacillus strains & Silver & $15-500$ & $\begin{array}{l}\text { Crystalline, hexagonal, triangular, and } \\
\text { cluster }\end{array}$ & {$[38]$} \\
\hline Lactobacillus strains & Silver-gold alloys & $100-300$ & Crystalline and cluster & {$[38]$} \\
\hline Lactobacillus strains & Titanium & $40-60$ & Spherical & {$[39]$} \\
\hline Lactobacillus casei subsp. casei & Silver & $25-50$ & Spherical & {$[12]$} \\
\hline $\begin{array}{l}\text { Magnetospirillum } \\
\text { magnetotacticum }\end{array}$ & Magnetite & - & $\begin{array}{l}\text { Cluster (folded-chain and flux-closure } \\
\text { ring) }\end{array}$ & {$[40]$} \\
\hline Nocardiopsis sp. MBRC-1 & Silver & $\sim 45$ & Spherical & {$[41]$} \\
\hline Plectonema boryanum UTEX 485 & Gold & $\begin{array}{l}10-25 \text { and } \\
\sim 1-10 \text { and } \\
10 \text { to } 6000\end{array}$ & Cubic and octahedral Platelet & {$[42,43]$} \\
\hline Pseudomonas aeruginosa & Gold & $15-30$ & - & {$[44]$} \\
\hline Pseudomonas aeruginosa & Lanthanum & - & Crystalline and needle-like & {$[12,14]$} \\
\hline Pseudomonas fluorescens & Gold & $50-70$ & Spherical & {$[45]$} \\
\hline $\begin{array}{l}\text { Pseudomonas putida } \\
\text { NCIM } 2650\end{array}$ & Silver & $\sim 70$ & Spherical & {$[46]$} \\
\hline $\begin{array}{l}\text { Pseudomonas } \\
\text { stutzeri AG259 }\end{array}$ & Silver & $\begin{array}{l}35-46 \text { and } \\
\text { up to } 200\end{array}$ & $\begin{array}{l}\text { Hexagonal, equilateral triangle, } \\
\text { crystalline silver, and monoclinic silver } \\
\text { sulfide acanthite }\end{array}$ & {$[47]$} \\
\hline Rhodobacter sphaeroides & Zinc sulfide & $\begin{array}{l}\text { Average diameter } \\
\text { of } 8\end{array}$ & Spherical & {$[48]$} \\
\hline Rhodopseudomonas capsulata & Gold & $10-20$ & Nanoplate and spherical & {$[15,49]$} \\
\hline
\end{tabular}


TABle 1: Continued.

\begin{tabular}{|c|c|c|c|c|}
\hline Bacteria & Nanoparticle & Size $(\mathrm{nm})$ & Morphology & References \\
\hline $\begin{array}{l}\text { Rhodopseudomonas } \\
\text { palustris }\end{array}$ & Cadmium sulfide & $8.01 \pm 0.25$ & Crystalline, face-centered cubic & {$[50]$} \\
\hline Serratia nematodiphila & Silver & $10-31$ & spherical, and crystalline & {$[51]$} \\
\hline Shewanella algae & Platinum & 5 & elemental & {$[52]$} \\
\hline Shewanella algae strain BRY & Gold & $\begin{array}{l}\text { Various sizes } \\
\text { changed with } \mathrm{pH}\end{array}$ & - & {$[28]$} \\
\hline $\begin{array}{l}\text { Shewanella putrefaciens } \\
\text { (Gs-15) }\end{array}$ & Magnetite & $10-50$ & Fine-grained crystal & {$[53]$} \\
\hline $\begin{array}{l}\text { Thermoanaerobacter ethanolicus } \\
\text { TOR-39 }\end{array}$ & $\begin{array}{l}\text { Magnetite, } \\
\text { cobalt, nickel, and } \\
\text { chromium }\end{array}$ & - & Octahedral & {$[13,54]$} \\
\hline
\end{tabular}

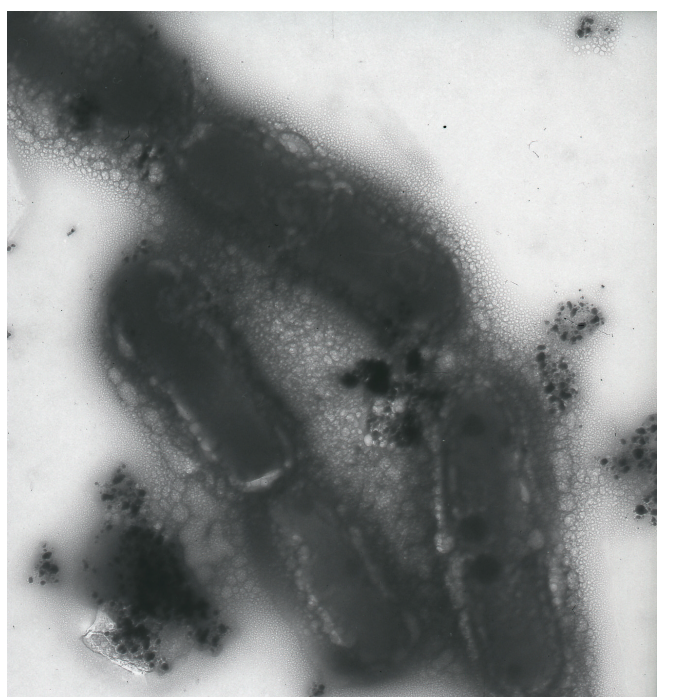

FIGURE 1: Our research group demonstratedthe bioreductive synthesis of silver NPs using Lactobacillus casei subsp. casei (an unpublished TEM image recorded from silver NPs synthesized by reaction of silver nitrate solution $(1 \mathrm{mM})$ with $L$. casei subsp. casei).

aggregates $(\sim 100 \mathrm{~nm})$, attached to the surface of biomass or were inside and outside of the cells. The bioreduction of metal ions and stabilization of the silver NPs were confirmed to occur by an enzymatic process. Electron microscopy analysis indicated that the silver NPs were formed on the surface of the cytoplasmic cell membrane, inside the cytoplasm and outside of the cells, possibly due to the bioreduction of the metal ions by enzymes present on the cytoplasmic membrane and within the cytoplasm [12].

A number of metal-reducing bacteria have been isolated and characterized from a variety of habitats, and much work has focused on Shewanella oneidensis and Geobacter spp. [66]. The biosynthesis of extracellular silverbased single nanocrystallites of well-defined composition and homogeneous morphology utilizing the $\gamma$-proteobacterium, $S$. oneidensis MR-1, upon incubation with aqueous silver nitrate solution was reported. Further characterization of these particles revealed that the crystals consist of small, reasonably monodispersed spheres in the $2-11 \mathrm{~nm}$ size range $(\sim 4 \pm 1.5 \mathrm{~nm})$ [67].

The rapid biosynthesis of silver NPs using the bioreduction of aqueous $\mathrm{Ag}^{+}$ion by the culture supernatants of Klebsiella pneumonia, E. coli, and Enterobacter cloacae (Enterobacteriaceae) was reported [37]. The synthetic process was quite fast and the produced NPs were formed within 5 min of silver ions coming in contact with the cell filtrate. Piperitone (a natural product which show an inhibitory effect on nitro reduction activity of Enterobacteriaceae) could partially inhibit the bioreduction of silver ions to silver NPs by different strains of Enterobacteriaceae including $K$. pneumoniae. As a result of this control experiment, nitroreductase enzymes might be responsible for bioreduction of silver ions. Recently, it was shown that visible-light emission could significantly prompt synthesis of silver NPs by culture supernatants of K. pneumoniae [68]. Silver NPs with uniform size and shape $(\sim 1-6 \mathrm{~nm})$ were biosynthesized using silver chloride (as the substrate).

When some quantities of $\mathrm{NaOH}$ were added to the bioreduction system, silver NPs were successfully prepared with reduction of $\left[\mathrm{Ag}\left(\mathrm{NH}_{3}\right)_{2}\right]^{+}$by Aeromonas sp. SH10 and Corynebacterium sp. SH09 [69]. It was speculated that $\left[\mathrm{Ag}\left(\mathrm{NH}_{3}\right)_{2}\right]^{+}$first reacted with $\mathrm{OH}^{-}$to form $\mathrm{Ag}_{2} \mathrm{O}$, which was then metabolized independently and reduced to silver NPs by the biomass. The color of the bioreduction system changed from pale yellow to dark yellow. The silver NPs were monodispersed and uniform in size without distinct aggregation and it was observed that the solution containing the NPs remained stable for more than six months. The color change indicated the formation of silver NPs in the reaction mixture, as it is well-known that silver NPs exhibit striking colors (light yellow to brown) due to excitation of surface plasmon vibrations (SPV) in the particles [70].

2.2. Gold NPs. It was reported that Bacillus subtilis 168 was able to reduce $\mathrm{Au}^{3+}$ ions to octahedral gold NPs $(\sim 5-25 \mathrm{~nm})$ within bacterial cells by incubation of the cells with gold chloride under ambient temperature and pressure conditions $[20,21]$. The reduction processes of chloroaurate and silver ions by B. subtilis were found to be different [71]. Gold NPs were biosynthesized both intracellularly and extracellularly, while silver NPs were exclusively formed extracellularly. 
The gold NPs were formed after one day of addition of chloroaurate ions, while the silver NPs were formed after seven days. Transmission electron microscopy (TEM) micrographs depicted the formation of gold NPs intracellularly and extracellularly, which had an average size of $7.6 \pm 1.8$ and $7.3 \pm$ $2.3 \mathrm{~nm}$, respectively, while silver NPs were exclusively formed extracellularly, with an average size of $6.1 \pm 1.6 \mathrm{~nm}$. The bacterial proteins were analyzed by sodium dodecyl sulfonatepolyacrylamide electrophoresis (SDS-PAGE) before and after the addition of metal ion solutions. Satyanarayana et al. reported that proteins of a molecular weight between 25 and $66 \mathrm{kDa}$ could be responsible for chloroaurate ions reduction, while the formation of silver NPs could be attributed to proteins of a molecular weight between 66 and $116 \mathrm{kDa}$. They reported that the NPs were stabilized by the surface-active molecules, that is, surfactin or other biomolecules released into the solution by $B$. subtilis.

Bacillus megaterium D01 have shown the strong potential of $\mathrm{Au}^{3+}$ adsorption [19]. When B. megaterium D01 biomass was exposed to the aqueous solution of $\mathrm{HAuCl}_{4}$, monodispersed spherical gold NPs capped with self-assembled monolayer (SAM) of thiol of $1.9 \pm 0.8 \mathrm{~nm}$ sizes have been synthesized, extracellularly. The gold NPs were stable without any aggregation over a period of several weeks. Therefore, by addition of dodecanethiol (as the capping ligand) into the reaction mixture monodispersed spherical gold NPs were produced. Moreover, Lactobacillus strains, when exposed to gold ions, resulted in formation of gold NPs within the bacterial cells [38]. It was reported that exposure of lactic acid bacteria present in the whey of buttermilk to mixtures of gold ions could be used to grow gold NPs. The nucleation of gold NPs occurred on the cell surface through sugars and enzymes in the cell wall, and then the metal nuclei were transported into the cell where they aggregated to larger-sized particles.

All members of the genus Shewanella reported so far are facultatively anaerobic, gram-negative, motile by polar flagella, rod-like, and generally associated with aquatic or marine habitats [72-79]. Most of Shewanella species are mesophilic, psychrotolerant, and psychrophilic bacteria [72, 80]. Shewanella alga is a gram-negative bacillus, which is widely distributed in the environment, and its natural habitats are water and soil [81]. Konishi et al. [82] reported microbial deposition of gold NPs using $S$. algae. This bacteriumcan grow anaerobically in medium with lactate or $\mathrm{H}_{2}$ as the electron donor and Fe (III) citrate as the electron acceptor. They demonstrated that resting cells of $S$. algae were capable of reducing $\mathrm{AuCl}_{4}{ }^{-}$ions $(1 \mathrm{mM})$ into elemental gold within $30 \mathrm{~min}$ at $25^{\circ} \mathrm{C}$ over the $\mathrm{pH}$ range from 2.0 to 7.0 , when $\mathrm{H}_{2}$ gas was provided as the electron donor [83]. At $\mathrm{pH} 7.0$, biogenic gold NPs $(\sim 10-20 \mathrm{~nm})$ were deposited in the periplasmic space of $S$. algae cells. When the solution $\mathrm{pH}$ decreased to below 2.8, some gold NPs were deposited extracellularly. At this $\mathrm{pH}$, the biogenic gold NPs $(\sim 15-200 \mathrm{~nm})$ on the bacterial cells exhibited various morphologies. At a solution of $\mathrm{pH} 2.0$, biogenic gold NPs $(\sim 20 \mathrm{~nm})$ were deposited on the bacterial cells, and larger gold particles $(\sim 350 \mathrm{~nm})$ were deposited extracellularly. Thus, it could be concluded that the solution $\mathrm{pH}$ is an important factor in controlling the morphology of biogenic gold NPs and in the location of gold deposition [82]. They observed that the decrease in the soluble Au (III) concentration was presumably caused by its rapid reduction into insoluble gold. In the absence of $\mathrm{H}_{2}$ gas, however, $S$. algae cells were not able to reduce $\mathrm{Au}$ (III) with lactate as an alternative electron donor. Moreover, in a sterile control medium without $S$. algae cells, Au (III) was not chemically reduced by $\mathrm{H}_{2}$ gas. Thus, resting cells of $S$. algae were able to reduce the soluble $\mathrm{Au}$ (III) into insoluble gold in the presence of molecular $\mathrm{H}_{2}$ as the electron donor $[28,84]$.

Escherichia coli $\mathrm{DH} 5 \alpha$ can be used in synthesizing gold NPs $(\sim 25 \pm 8 \mathrm{~nm})$ [33]. Shapes and sizes of the NPs were not homogenous. They were mostly spherical and a few amounts of triangles and quasi-hexagons were observed, as well. TEM micrographs showed that gold NPs were bound on the surface of the bacteria. Using E. coli-gold NPs composite, Liangwei et al. made an Hb-coli-nAu-Glassy Carbon electrode, which could be used to achieve the direct electrochemistry of hemoglobin. In another study, biorecovery of gold from jewellery wastes was obtained using E. coli MC4100 (nonpathogenic strain) and Desulfovibrio desulfuricans ATCC 29577 [34]. When these bacteria were exposed to $\mathrm{HAuCl}_{4}$ solution $(2 \mathrm{mM})$, gold NPs was formed. In order to control size and shape of the NPs, Deplanche et al. investigated the influence of $\mathrm{pH}$ on $\mathrm{Au}$ (III) bioreduction using E. coli and $D$. desulfuricans. At acidic $\mathrm{pH}$, spherical gold NPs (less than $10 \mathrm{~nm}$ diameter) were produced, but at $\mathrm{pH} 7.0$ and 9.0, a mixture of smaller $(\sim 10 \mathrm{~nm})$ and bigger $(\sim 50 \mathrm{~nm})$ welldefined triangles, hexagons, and rods were formed.

Rhodopseudomonas capsulata showed the ability to produce gold NPs in different sizes, and the shape of gold NPs was controlled by $\mathrm{pH}[15]$. $R$. capsulate was capable of producing gold NPs extracellularly and the gold NPs were quite stable in the solution. The aqueous chloroaurate ions were reduced during exposure to the biomass and the color of the reaction solution turned from pale yellow to purple. When the $\mathrm{pH}$ was adjusted to 4 , a number of nanoplates were observed in addition to the spherical gold NPs in the reaction solution. Size and morphology of gold NPs might be affected by $\mathrm{AuCl}_{4}{ }^{-}$ions concentration. At lower concentration of $\mathrm{AuCl}_{4}{ }^{-}$ions as the substrate, spherical gold NPs $(\sim 10-20 \mathrm{~nm})$ were synthesized exclusively, while at higher concentrations, networked gold nanowires were produced in the aqueous solution [49]. The $\mathrm{AuCl}_{4}{ }^{-}$ions could bind to the biomass through the main groups of secreted enzymes. These enzymes showed an important role in reduction of $\mathrm{AuCl}_{4}{ }^{-}$ions. Bioreduction of $\mathrm{Au}(3+)$ to $\mathrm{Au}(0)$ and formation of gold NPs might be due to NADH dependent enzymes which were secreted by R. capsulate. The mechanism of reduction seemed to be initiated by electron transfer from NADH by NADH dependent reductase as the electron carrier.

Lengke et al. [42] controlled morphology of gold NPs using filamentous cyanobacteria, such as Plectonema boryanum UTEX 485 . They produced cubic gold NPs $(<10-$ $25 \mathrm{~nm})$ and octahedral gold platelets $(\sim 1-10 \mu \mathrm{m})$ interacting $P$. boryanum UTEX 485 with aqueous $\mathrm{Au}\left(\mathrm{S}_{2} \mathrm{O}_{3}\right)_{2}{ }^{3-}$ and $\mathrm{AuCl}_{4}{ }^{-}$solutions at $25-100^{\circ} \mathrm{C}$ for up to 1 month and at $200^{\circ} \mathrm{C}$ for one day. The interaction of cyanobacteria with aqueous 
$\mathrm{Au}\left(\mathrm{S}_{2} \mathrm{O}_{3}\right)_{2}{ }^{3-}$ promoted the precipitation of cubic gold NPs at membrane vesicles and admixed with gold sulfide within the cells and encrusted on the cyanobacteria, whereas reaction with $\mathrm{AuCl}_{4}{ }^{-}$resulted in the precipitation of octahedral gold platelets in solutions and NPs of gold $(<10 \mathrm{~nm})$ within bacterial cells. Moreover, the mechanisms of gold bioaccumulation by cyanobacteria from gold (III)-chloride solutions have shown that the interaction of cyanobacteria with aqueous gold (III)-chloride initially promoted the precipitation of NPs of amorphous gold (I)-sulfide at the cell walls and finally deposited metallic gold in the form of octahedral (III) platelets $(\sim 10 \mathrm{~nm}-6 \mu \mathrm{m})$ near cell surfaces and in solutions [43].

Plant-growth-promoting bacteria isolated from Philippine soils were screened for their ability to extracellularly synthesize gold NPs. Extracellular synthesis of gold NPs $(\sim 10-100 \mathrm{~nm})$ was determined by incubation of the plantgrowth-promoting culture supernatant with gold (III) chloride trihydrate $\left(\mathrm{HAuCl}_{4} \cdot 3 \mathrm{H}_{2} \mathrm{O}\right)$ for 7 days at $28^{\circ} \mathrm{C}$. It was suggested that nitrate reductase was one of the enzymes responsible in the bioreduction of ionic gold [85].

2.3. Magnetite NPs. Desulfovibrio magneticus strain RS-1 is an anaerobic sulfate-reducing bacterium which also respires and grows with fumarate as the terminal electron acceptor [86]. D. magneticus strain RS-1 accumulated magnetite NPs intracellularly. Most magnetite crystals in the cells were only slightly larger than $30 \mathrm{~nm}$ (super paramagnetic NPs) [29]. Klaus-Joerger reported that metals including $\mathrm{Co}, \mathrm{Cr}$, and $\mathrm{Ni}$ might be substituted into magnetite crystals biosynthesized in the thermophilic iron-reducing bacterium Thermoanaerobacter ethanolicus (TOR-39) [13, 54, 87]. This procedure led to formation of octahedral-shaped magnetite $\left(\mathrm{Fe}_{3} \mathrm{O}_{4}\right) \mathrm{NPs}$ $(<12 \mathrm{~nm})$ in large quantities that coexisted with a poorly crystalline magnetite phase near the surface of the cells [87]. A more fundamental investigation in the assembly of single-domain magnetite particles into folded-chain and flux-closure ring morphologies by harvested magnetotactic bacterium, Magnetospirillum magnetotacticum, was carried out by Philipse and Maas [40]. Magnetic NPs were also assembled into ordered structures when the motion of $M$. magnetotacticum (MS-1) was controlled by applying a magnetic field [88].

Fe (III) is an important oxidant of natural and contaminant organic compound in surface and subsurface aquatic sediments $[89,90]$. Fe (III) and Mn (IV) could influence the inorganic geochemistry of sedimentary environment by greatly increasing the dissolved concentration of iron, trace metal, manganese, and phosphate [91, 92]. Sulfatereducing bacteria were capable of producing magnetic iron sulfide (FeS) NPs. Adsorption of radioactive metals by these magnetic iron sulfide NPs occurred due to high surface area $\left(400-500 \mathrm{~m}^{2} / \mathrm{g}\right)$ which could provide a suitable matrix for the long-term safe storage of hazardous radioactive pertechnetate ion $[93,94]$. GS-15 (an obligately anaerobic, gram-negative rod) oxidized simple organic compounds such as acetate, butyrate, and ethanol to carbon dioxide with $\mathrm{Fe}$ (III) or Mn (IV) as the sole electron acceptor [53, 95]. Iron-reducing microorganism, GS-15, produced copious quantities of ultrafine-grained magnetite, with size range of 10 to $50 \mathrm{~nm}$, under anaerobic conditions by coupling the organic matter to the reduction of ferric iron [53]. In this process, the nonmagnetic brown amorphic ferric oxide was converted to a black solid material which was strongly attracted to a magnet. But GS-15 was not magnetotactic because the crystals were clearly external to the cells and were not aligned in chains. Lovely et al. [96] investigated the ability of Alteromonas putrefaciens to couple the oxidation of potential electron donors (such as lactate, pyruvate, hydrogen, and formate) to the reduction of $\mathrm{Fe}$ (III) and $\mathrm{Mn}$ (IV). Also they reported that Pelobacter acetylenicus and $P$. venetianus were able to reduce Fe (III). They demonstrated that $P$. carbinolicus was capable of conversing energy to support growth from Fe (III) respiration as it also grew with $\mathrm{H}_{2}$ or formate as the electron donor and Fe (III) as the electron acceptor. P. carbinolicus grew with ethanol (ethanol was metabolized to acetate) as the sole electron donor and Fe (III) as the sole electron acceptor. Growth was also possible on Fe (III) with the oxidation of propanol to propionate or butanol to butyrate if acetate was provided as a carbon source [97].

Jahn et al. [98] discovered a novel mechanism for electron transfer from iron-reducing microorganisms to insoluble iron phases. They monitored iron reduction kinetics with soluble electron acceptors such as ferric citrate, ferrihydrite colloids, and solid ferrihydrite. Roden and Lovley [99] have demonstrated that the marine strain of Desulfuromonas acetoxidans was capable of dissimilatory $\mathrm{Fe}$ (III) and $\mathrm{Mn}$ (IV) reduction. They reported that washed cell suspensions of the type strain of D. acetoxidans reduced soluble Fe (III)citrate and Fe (III) complexed with nitriloacetic acid. Ethanol, propanol, pyruvate, and butanol served as electron donors for Fe (III) reduction, as well. In addition, Kashefi and Lovley [100] reported that $P$. islandicum owns the ability to reduce $\mathrm{Fe}$ (III) at $100^{\circ} \mathrm{C}$ in a medium with hydrogen as the electron donor and $\mathrm{Fe}$ (III)-citrate as the electron acceptor. Cell suspensions of $P$. islandicum reduced the following metals with hydrogen as the electron donor: U (VI), Tc (VII), Cr (VI), Co (III), and Mn (IV). The reduction of these metals was dependent upon the presence of cells and hydrogen. In contrast, $P$. islandicum could not reduce As (V) or Se (VII). Reducing varieties of metals by $P$. islandicum plays an important role in geological phenomena and have application for remediation of metal contaminated water. Thermus specieswere able to reduce $\mathrm{U}(\mathrm{VI}), \mathrm{Cr}(\mathrm{VI})$, and Co (III) at $60^{\circ} \mathrm{C}$ [101]. Thermophilic $\left(45\right.$ to $\left.75^{\circ} \mathrm{C}\right)$ bacteria showed the ability to reduce amorphous Fe (III)-oxyhydroxide to magnetic iron oxides [102]. They could reduce Cr (VI) and Co (III) at temperatures of up to $65^{\circ} \mathrm{C}$, as well [103]. Hyperthermophilic metal reducing microorganisms could help preventing migration of these contaminants by reducing them to less mobile forms. Hot radioactive or metalcontaining industrial wastes could potentially be treated in bioreactors containing microorganisms with a metabolism like that of P. islandicum or their enzymes [100].

Many mesophilic microorganisms which own the ability to use Fe (III) as a terminal electron acceptor could also reduce a variety of metals and metalloids other than $\mathrm{Fe}$ (III) $[104,105]$. Fe (III)-reducing bacteria and archaea were 
capable of precipitating gold by reducing $\mathrm{Au}$ (III) to $\mathrm{Au}$ (0) [28]. The reaction seemed to be enzymatically catalyzed which were dependent on temperature and the presence of hydrogen (as a specific electron donor). Many Fe (III)reducing microorganisms could reduce forms of oxidized metals, including radio nuclides such as uranium (VI) [89, 95-101] and technetium (VII) [28, 89, 98-103] and trace metals including arsenic (V) $[30,106]$, chromium (VI) [89, $92,94,98,104,105]$, cobalt (III) $[1,15,30,89,92,106]$, manganese (IV) [100, 107], and selenium (VI) [82, 108]. Many of these metals and metalloids are environmental contaminants. Therefore, Fe (III)-reducing microorganisms could be used for removal of contaminant metals from waters and waste streams and immobilization of metals in subsurface environments. Microbial reduction of some of these metals may also play an important role in the formation of metal deposits, which may be especially important in hot environments containing metal-rich waters [33, 107-111]. Common product of bacterial iron reduction nanosized magnetic particles, enabled early disease detection and accurate prognosis, and personalized treatment, monitoring efficacy of a prescribed therapy, or study of cellular interaction in a certain biological environment $[109,110]$. These particles might have different applications in radionuclide therapy, drug delivery, magnetic resonance imaging (MRI), diagnostics, immunoassays, molecular biology, DNA and RNA purification, cell separation and purification, cell adhesion research, hyperthermia $[111,112]$, and magnetic ferrofluids for magnetocaloric pumps $[113,114]$.

2.4. Palladium and Platinum NPs. The sulfate-reducing bacterium, Desulfovibrio desulfuricans $[27,115]$, and metal ionreducing bacterium, Shewanella oneidensis, were capable of reducing soluble palladium (II) into insoluble palladium (0) with formate, lactate, pyruvate, or $\mathrm{H}_{2}$ as the electron donor [116]. Konishi et al. [52] demonstrated that resting cells of $S$. algae were able to deposit platinum NPs by reducing $\mathrm{PtCl}_{6}{ }^{2-}$ ions within $60 \mathrm{~min}$ at $\mathrm{pH} 7$ and $25^{\circ} \mathrm{C}$. Biogenic platinum NPs of about $5 \mathrm{~nm}$ were located in the periplasmic space. In this case, the cell suspension changed the color from pale yellow to black in $10 \mathrm{~min}$. The black appearance provided a convenient visible signature for the microbial formation of metallic platinum NPs. The observed decrease in aqueous platinum concentration was presumably caused by the rapid reduction of $\mathrm{PtCl}_{6}{ }^{2-}$ ions into insoluble platinum. In the absence of lactate, however, $S$. algae cells were not able to reduce the $\mathrm{PtCl}_{6}{ }^{2-}$ ions. They reported that the $\mathrm{PtCl}_{6}{ }^{2-}$ ions were not chemically reduced by lactate. Yong et al. [117] also reported that the sulfate-reducing bacterium $D$. desulfuricans was able to adsorb only $12 \%$ of platinum (IV) ions on the bacterial cells from $2 \mathrm{mM}$ platinum chloride solution. In another study, Gram-negative cyanobacterium, P. boryanum UTEX 485, extracellularly produced Pt (II)-organics and metallic platinum NPs at $25-100^{\circ} \mathrm{C}$ for up to 28 days and $180^{\circ} \mathrm{C}$ for 1 day with different morphologies of spherical, bead-like chains and dendritic in the size range of $30 \mathrm{~nm}-$ $0.3 \mu \mathrm{m}[118]$.
2.5. Selenium and Tellurium NPs. Selenium has photooptical and semiconducting properties that have applications in photocopiers and microelectronic circuit devices. Stenotrophomonas maltophilia SELTE02 showed promising transformation of selenite $\left(\mathrm{SeO}_{3}{ }^{-2}\right)$ to elemental selenium $\left(\mathrm{Se}^{0}\right)$ accumulating selenium granules either in the cell cytoplasm or in the extracellular space. In addition, Enterobacter cloacae SLD1a-1, Rhodospirillum rubrum, and Desulfovibrio desulfuricans have also been found to bioreduce selenite to selenium both inside and outside the cell with various morphologies like spherical, fibrillar, and granular structure or with small atomic aggregates. E. coli also deposited elemental selenium both in periplasmic space and cytoplasm, and $P$. stutzeri also aerobically reduced selenite to elemental selenium [119]. Under aerobic conditions, Hunter and Manter [120] reported that Tetrathiobacter kashmirensis bioreduced selenite to elemental red selenium. A $90-\mathrm{kDa}$ protein present in the cell-free extract was believed to be responsible for this bioreduction. Moreover, Yadav et al. [121] showed that $P$. aeruginosa SNT1 biosynthesized nanostructured selenium by biotransforming selenium oxyanions to spherical amorphous allotropic elemental red selenium both intracellularly and extracellularly. In addition, Sulfurospirillum barnesii, Bacillus selenitireducens, and Selenihalanaerobacter shriftii synthesized extracellularly stable uniform nanospheres $(\sim 300 \mathrm{~nm})$ of elemental selenium $\mathrm{Se}^{0}$ with monoclinic crystalline structures [122]. Microbial synthesis of elemental selenium $\left(\mathrm{Se}^{0}\right)$ nanospheres resulted in unique, complex, compacted nanostructured arrangements of Se atoms. These arrangements resulted due to the dissimilatory reductions that were subtly different in different microbes. In another study, stable, predominantly monodispersed, and spherical selenium NPs (with an average size of $21 \mathrm{~nm}$ ) were synthesized using the bacterial isolate Pseudomonas aeruginosa strain JS-11. The bacteria exhibited significant tolerance to selenite $\left(\mathrm{SeO}_{3}{ }^{2-}\right)$ up to $100 \mathrm{mM}$ concentration with an $\mathrm{EC}_{50}$ value of $140 \mathrm{mM}$. The culture supernatant contained the potential of reducing soluble and colorless $\mathrm{SeO}_{3}{ }^{2-}$ to insoluble red elemental selenium $\left(\mathrm{Se}^{0}\right)$ at $37^{\circ} \mathrm{C}$. It was suggested that the metabolite phenazine-1-carboxylic acid released by strain JS-11 in culture supernatant along with the known redox agents like $\mathrm{NADH}$ and $\mathrm{NADH}$ dependent reductases was responsible for biomimetic reduction of $\mathrm{SeO}_{3}{ }^{2-}$ to $\mathrm{Se}^{0}$ nanospheres. The authors elucidated that the red colored $\mathrm{Se}^{0}$ nanospheres may serve as a biosensor for nanotoxicity assessment, contemplating the inhibition of $\mathrm{SeO}_{3}{ }^{2-}$ bioreduction process in NPs treated bacterial cell culture supernatant, as a toxicity end point. In other words, the formation of red $\mathrm{Se}^{0}$ from $\mathrm{SeO}_{3}{ }^{2-}$ could serve as a molecular marker, whereas the inhibition of critical bioreduction step was considered as a toxicity end point for the qualitative and quantitative toxicity assessment [123].

Tellurium (Te) has been reduced from tellurite to elemental tellurium by two anaerobic bacteria, Bacillus selenitireducens and Sulfurospirillum barnesii. B. selenitireducens initially formed nanorods of $10 \mathrm{~nm}$ in diameter and $200 \mathrm{~nm}$ in length were clustered together to form larger rosettes of $\sim 1000 \mathrm{~nm}$ but with $S$. barnesii small irregularly shaped 
extracellular nanospheres of diameter $<50 \mathrm{~nm}$ were formed [124]. In another study, tellurium-transforming Bacillus sp. BZ isolated from the Caspian Sea in northern Iran was used for the intracellular biosynthesis of elemental tellurium NPs. The biogenic NPs were released by liquid nitrogen and purified by an n-octyl alcohol water extraction system. TEM analysis showed rod-shaped NPs with dimensions of about $20 \mathrm{~nm} \times 180 \mathrm{~nm}$. The produced NPs had a hexagonal crystal structure [125].

2.6. Zinc Oxide NPs. Zinc oxide ( $\mathrm{ZnO})$ NPs have unique optical and electrical properties, and as a wide band gap semiconductor, they have found more uses in biosensors, nanoelectronics, and solar cells. These NPs are being used in the cosmetic and sunscreen industry due to their transparency and ability to reflect, scatter, and absorb UV radiation and as food additives. Furthermore, zinc oxide NPs are also being considered for use in next-generation biological applications including antimicrobial agents, drug delivery, and bioimaging probes [126]. A low-cost and simple procedure for synthesis of zinc oxide NPs using reproducible bacterium, Aeromonas hydrophila, was reported. X-ray diffraction (XRD) confirmed the crystalline nature of the NPs, and atomic force microscopy (AFM) showed the morphology of the nanoparticle to be spherical, oval with an average size of $57.72 \mathrm{~nm}$. The antibacterial and antifungal activity was ended with corresponding well diffusion and minimum inhibitory concentration. The maximum zone of inhibition was observed in the $\mathrm{ZnO}$ NPs $(25 \mu \mathrm{g} / \mathrm{mL})$ against Pseudomonas aeruginosa $(\sim 22 \pm 1.8 \mathrm{~mm})$ and Aspergillus flavus $(\sim 19 \pm 1.0 \mathrm{~mm})[126]$.

2.7. Titanium and Titanium Dioxide NPs. Spherical titanium (Ti) NPs ( 40-60 nm) were produced extracellularly using the culture filtrate of Lactobacillus sp. at room temperature [39]. These NPs were lighter in weight and have high resistance to corrosion and have enormous applications in automobiles, missiles, airplanes, submarines, cathode ray tubes, and desalting plants and have promising future role in cancer chemotherapy and gene delivery. $\mathrm{TiO}_{2}$ (titanium dioxide) NPs has been explored in various biomedical applications such as wound dressing, biosensing, contrast agents, targeted drug delivery agents, antiwrinkle, and antimicrobial and antiparasitic agents owing to their nontoxic and biocompatible properties [127]. These NPs were biologically synthesized by using Bacillus subtilis. The morphological characteristics were found to be spherical, oval in shape, individual NPs as well as a few aggregates having the size of 66-77 nm. The XRD shows the crystallographic plane of anatase of titanium dioxide NPs, indicating that NPs structure dominantly corresponds to anatase crystalline titanium dioxide [128]. In another study, biosynthesis of titanium dioxide NPs by a metal resistant bacterium isolated from the coal fly ash effluent was reported. The bacterial strain on the basis of $16 \mathrm{~S}$ rDNA technique and the biochemical parameters was identified to be Propionibacterium jensenii [KC545833], a probiotic, high G + C rich, pleomorphic rod shaped gram-positive bacteria. The produced NPs were smooth and spherical in shape and ranged in size from 15 to $80 \mathrm{~nm}$ [127].

2.8. Cadmium Sulphide NPs. Several investigations have shown that cadmium sulphide particles could be microbially produced in Klebsiella aerogenes [36] and the yeasts such as Candida glabrata and Schizosaccharomyces pombe $[129,130]$. Holmes et al. [36] have demonstrated that the exposure of the bacterium, $K$. aerogenes, to $\mathrm{Cd}^{2+}$ ions resulted in the intracellular formation of CdS NPs in the size range of 20$200 \mathrm{~nm}$. They also showed that the buffer composition of the growth medium plays an important role in formation of cadmium sulfide crystallites. Cadmium sulphide uptake by $K$. aerogenes cells grown in the presence of $2 \mathrm{mM} \mathrm{Cd}\left(\mathrm{NO}_{3}\right)_{2}$ could be up to approximately $20 \%$ of the total biomass [36].

Synthesis of semiconductor NPs such as CdS, ZnS, and $\mathrm{PbS}$ for application as quantum-dot fluorescent biomarkers and cell labeling agents was reported [131]. These luminescent quantum dots are emerging as a new class of materials for biological detection and cell imaging, based on the conjugation of semiconducting quantum dots and biorecognition molecules. Bacteria have been used with considerable success in the synthesis of CdS NPs [33, 85, 94]. Clostridium thermoaceticum (an acetogenic bacterium) showed the ability to grow autotrophically on $\mathrm{CO}_{2}$ and $\mathrm{H}_{2}$, utilizing the so-called Wood-Ljungdahl pathway to synthesize acetyl coenzyme A (acetyl-CoA), a starting material for the anabolic processes of these cells [132]. Cunningham et al. [23] reported that C. thermoaceticum was able to precipitate cadmium extracellularly at an initial concentration of $1 \mathrm{mM}$. This process was energy dependent and required cysteine. The yellow precipitate of CdS appeared approximately $12 \mathrm{~h}$ after the addition of $\mathrm{CdCl}_{2}$ and complete removal of the metal from the growth medium was accomplished within $72 \mathrm{~h}$. CdS was precipitated from $\mathrm{CdCl}_{2}$ in the presence of cysteine hydrochloride by $C$. thermoaceticum at the cell surface and in the medium [23]. Rhodopseudomonas palustris was capable of producing cadmium sulfide NPs when it was incubated with $1 \mathrm{mM} \mathrm{CdSO}_{4}$ at $30^{\circ} \mathrm{C}$ for $72 \mathrm{~h} \mathrm{[50].} \mathrm{The} \mathrm{researchers} \mathrm{of} \mathrm{this}$ study found that C-S-lyase (an intracellular enzyme located in the cytoplasm) was responsible for the synthesis of NPs. One of the interesting results of this study was that $R$. palustris transported CdS NPs out of the cell.

In another case, E. coli, when incubated with cadmium chloride $(1 \mathrm{mM})$ and sodium sulfide $(1 \mathrm{mM})$, showed the capacity to synthesize intracellular semiconductor cadmium sulfide (CdS) nanocrystals [30]. The nanocrystals were composed of a wurtzite crystal phase with a size distribution of 2$5 \mathrm{~nm}$. Nanocrystals formation varied dramatically depending on the growth phase of the cells. Scanning transmission electron microscopy (STEM) and high resolution transmission electron microscopy (HRTEM) revealed that nanocrystals formation increased about 20 -fold in E. coli grown in the stationary phase cells compared to late logarithmic phase cultures.

2.9. Zinc Sulfide NPs. Labrenz et al. [25] reported that spherical aggregates of 2 to $5 \mathrm{~nm}$ diameter sphalerite zinc sulfide 
$(\mathrm{ZnS})$ particles were formed within natural biofilms dominated by sulfate-reducing bacteria of the family of Desulfobacteraceae. A combination of geochemical and microbial processes led to $\mathrm{ZnS}$ biomineralization in a complex natural system. It is appropriate to mention that the concentration of $\mathrm{Zn}$ was significantly reduced to below-acceptable levels for drinking water with the use of this method. Rhodobacter sphaeroides has been developed for the synthesis of ZnS NPs with an average diameter of $8 \mathrm{~nm}$ [48]. In another study, ZnS NPs $(\sim 10.5 \pm 0.15 \mathrm{~nm})$ were produced by using $R$. sphaeroides [133].

\section{Mechanistic Aspects}

The ability of bacteria to survive and grow in stressful situations might be due to specific mechanisms of resistance which include efflux pumps, metal efflux systems, inactivation and complexation of metals, impermeability to metals and the lack of specific metal transport systems, alteration of solubility and toxicity by changes in the redox state of the metal ions, extracellular precipitation of metals, and volatilization of toxic metals by enzymatic reactions [134, 135]. For example, Pseudomonas stutzeri AG 259 isolated from silver mines has been shown to produce silver NPs [136]. There are several examples of microorganisms-metal interactions which are important in biotechnological applications, including the fields of biomineralization, bioremediation, bioleaching, and microbial-influenced corrosion (MIC) processes. Understanding of MIC processes in terms of microbially mediated localized changes in the surface chemistry of carbon steel, stainless steel, copper alloys, or other ones is gaining growing attention [137]. Bacteria also intervene in mineral precipitation reactions directly as catalysts of aqueous chemical reactions and indirectly as geochemically reactive solids [138] and showed the ability to oxidate minerals [139]. These processes are commercially used in bacterial leaching operations, such as the pretreatment of gold ores which contain arsenopyrite (FeAsS) [139].

Microbial metal reduction can be a strategy for in situ and $e x$ situ remediation of metal contaminations and wastes. In order to find out the relevance of nanoparticle synthesis and metal reduction, biorecovery of heavy metals, and bioremediation of toxic ones, researchers have investigated the mechanisms of nanoparticle synthesis and bioreduction and focused their attention on reducing agents in bacteria (e.g., proteins and enzymes) and biochemical pathways leading to metal ion reduction. Because of the critical role of these agents, there were more investigations in understanding the role and application of natural and genetically engineered bacterial strains and other microorganisms in bioremediation of toxic metals and radionuclide-contaminated terrestrial environments. Moreover, these microorganisms were capable of mobilization and immobilization of metals [140] and in some cases, the bacteria which could reduce metal ions showed the ability to precipitate metals at nanometer scale. These studies would then lead to check the possibility of genetically engineered microorganisms to overexpress specific reducing molecules and to develop microbial nanoparticle synthesis procedures, which might potentially control size, shape, stability, and yield of NPs. Actually, genetically engineered microorganisms have started being developed in order to increase protein secretion and thus elucidate the most probable reducing agent. For instance, Kang et al. [141] explored for the first time the systematic approach toward the tunable synthesis of semiconductor CdS nanocrystals by genetically engineered $E$. coli. To explore the feasibility of using E. coli as a biofactory for the controlled synthesis of CdS nanocrystals, a strain was endowed with the ability to produce phytochelatins (PCs) by expressing the PC synthetase of $S$. pombe (SpPCS). PCs serve as a binding template/nucleation site for the metal ions and stabilize the nanocrystal core against continued aggregation. A feedback-desensitized gamma-glutamylcysteine synthase $\left(\mathrm{GSHI}^{*}\right)$, which catalyzes the synthesis of the PC precursor glutathione (GSH), was cotransformed to enhance the level of PC synthesis 10-fold. After promoted PC synthesis, CdS nanocrystals were produced with a size distribution of 2$6 \mathrm{~nm}$. Moreover, it was proven that glutathione synthetase overexpression in ABLEC E. coli strains, in conjunction with metal stress, simultaneously enhanced the biosynthesis of intracellular glutathione and CdS NPs [142]. In another study, stable NPs were recently achieved using the engineering of the Desulfovibrio desulfuricans flagellar FliC protein. The introduction of additional cysteine-derived thiol residues in the E. coli FliC protein increased Au (III) sorption and reduction on the surface of the flagellar filament and resulted in the synthesis of stabilized gold NPs (20-50 nm). Exhibited biosorption values were about 3 times higher than in the wild type. Wild type flagellar filaments showed fewer gold NPs $(\sim 15-50 \mathrm{~nm})$ [34]. Moreover, a strain of Bacillus licheniformis was optimized for $\alpha$-amylase production for the synthesis of gold NPs $(10-50 \mathrm{~nm})$ [143]. Recombinant strains have been explored for developing more efficient organisms in the in vivo synthesis of NPs. For instance, recombinant E. coli strains expressing Arabidopsis thaliana phytochelatin synthase (AtPCS) and/or Pseudomonas putida metal-lothionein $(\mathrm{PpMT})$ were used for the synthesis of $\mathrm{Cd}, \mathrm{Se}, \mathrm{Zn}, \mathrm{Te}, \mathrm{Cs}$, $\mathrm{Sr}, \mathrm{Fe}, \mathrm{Co}, \mathrm{Ni}, \mathrm{Mn}, \mathrm{Au}, \mathrm{Ag} \mathrm{Pr}$, and Gd NPs. Adjusting the concentrations of supplied metal ions resulted in controlling the size of the metal NPs.

It was reported that the engineered E. coli system can be applicable to the biological synthesis of metal NPs [144]. Mutant strains of some bacteria used for synthesis of NPs could help to elucidate the molecules involved in the bioreduction process. For instance, three E. coli mutants lacking one or more of the [NiFe] hydrogenases appeared to exhibit altered patterns of $\mathrm{Pd}(0)$ deposition as compared to the parental strain. Mutant strains produced highly catalytic $\mathrm{Pd}$ NPs by bioreduction of Pd (II). These studies of hydrogenasedeficient mutants suggest that the location of the $\operatorname{Pd}(0)$ deposits is in accordance with the subcellular localization of the remaining active hydrogenase and that all three hydrogenases could contribute to Pd (II) reduction in vivo [145]. Besides, wild type and three hydrogenase-deficient strains of Desulfovibrio fructosivorans were used for the reduction of $\mathrm{Pd}$ (II) to $\mathrm{Pd}(0)$. The localization of palladium was coincident with the localization of the hydrogenase, suggesting that this enzyme serves as a nucleation site and assists initial Pd 
nanoparticle growth, probably by supplying the electrons for $\mathrm{Pd}$ (II) reduction [146].

In case of Acidithiobacillus thiooxidans, gold (I)-thiosulfate was entered into the cell of $A$. thiooxidans as part of a metabolic process [147]. This gold complex was initially decomplexed to $\mathrm{Au}(\mathrm{I})$ and thiosulfate $\left(\mathrm{S}_{2} \mathrm{O}_{3}{ }^{2-}\right)$ ions. Thiosulfate was used as energy source and $\mathrm{Au}(\mathrm{I})$ was presumably reduced to elemental gold within the bacterial cells. During the late stationary growth phase, the gold NPs which were initially precipitated inside the cells were released from the cells, resulting in the formation of gold particles at the cell surface. Finally, the gold particles in the bulk solution were grown into micrometer-scale wire and octahedral gold [147].

According to Lengke and Southam [148, 149], the precipitation of gold (I)-thiosulfate complex by sulfate-reducing bacteria was caused by three possible mechanisms: (a) iron sulfide formation, (b) localized reducing conditions, and (c) a metabolic process. In the iron system, the formation of iron sulfide generated by sulfate-reducing bacteria could have adsorbed a gold (I)-thiosulfate complex onto freshly forming surfaces, leading to the precipitation of elemental gold. The localized reducing conditions generated by sulfate-reducing bacteria were associated with metabolism. Thiosulfate ion from a gold (I)-thiosulfate complex was initially reduced to hydrogen sulfide $\left(\mathrm{HS}^{-}\right)$, as the end product of metabolism. The release of hydrogen sulfide through the outer membrane pores decreased redox conditions around the cells and caused the precipitation of elemental gold. The precipitation of elemental gold by sulfate-reducing bacteria through metabolic process was initiated when a gold (I)-thiosulfate entered the bacterial cells and was decomplexed to $\mathrm{Au}(\mathrm{I})$ and thiosulfate ions. Thiosulfate was used as energy source and $\mathrm{Au}(\mathrm{I})$ was presumably reduced to elemental gold within the bacterial cells. During the late stationary growth phase or death phase, the gold NPs which were initially precipitated inside the cells were released into the bulk solution and formed suboctahedral to octahedral, subspherical to spherical aggregates resembling framboids, and ultimately millimeter-thick gold foil at longer experimental duration $[148,149]$.

Several studies widely reported the act of cytoplasmic and periplasmic hydrogenases produced by microorganisms in metal reduction $[38,72]$. In order to show the critical role of these enzymes, researchers used $\mathrm{Cu}$ (II) as a selective inhibitor of periplasmic hydrogenases. For example, In case of $D$. desulfuricans and E. coli, partial inhibition of periplasmic hydrogenases with $\mathrm{Cu}$ (II) showed that these metal reductase enzymes play a role in Au (III) reduction [34]. Lioyd et al. [115] concluded that periplasmic hydrogenases were possibly responsible for $\mathrm{Pd}$ (II) reduction and inhibited by $\mathrm{Cu}$ (II). Furthermore, Au (III) reduction was done in the presence of $\mathrm{H}_{2}$ (as the electron donor) using microorganisms such as T. maritima, S. alga, D. vulgaris, G. ferrireducens, D. desulfuricans, and E. coli. Possibly, hydrogenases play an important role in $\mathrm{Au}$ (III) reduction [28, 34, 84], but more investigations were needed to know exact mechanisms of these reductions. Moreover, it was reported that hydrogenase is involved in $\mathrm{U}^{+6}$ reduction by Micrococcus lactyliticus [150], in addition to $\mathrm{Se}^{+6}$ reduction by Clostridium pasteurianum
[151]. Hydrogenases from the sulfate-reducing bacteria have been shown to be capable of reducing $\mathrm{Tc}^{+7}$ and $\mathrm{Cr}^{+6}$ [152]. In another study, it was reported that the hydrogenases isolated from phototrophic bacteria were able to reduce $\mathrm{Ni}^{+2}$ to $\mathrm{Ni}^{0}$ under an $\mathrm{H}_{2}$ atmosphere [153]. In case of S. algae, the microbial reduction of gold ions was dependent on the presence of a specific electron donor, the molecular $\mathrm{H}_{2}$. It was concluded that the $S$. algae hydrogenase catalyzes the activation of molecular $\mathrm{H}_{2}$ using the molecule as the electron donor according to the following reaction:

$$
\mathrm{H}_{2} \longrightarrow 2 \mathrm{H}^{+}+2 \mathrm{e}^{-}
$$

Therefore, the $S$. algae cells are likely to transfer electrons to $\mathrm{AuCl}_{4}{ }^{-}$ions, reducing them to gold metals. Consider

$$
\mathrm{AuCl}_{4}^{-}+3 \mathrm{e}^{-} \longrightarrow \mathrm{Au}+4 \mathrm{Cl}^{-} \text {. }
$$

In some cases, researchers purified proteins which were believed to be responsible for nanoparticle synthesis. Matsunaga et al. [154] have shown that MagA gene and its protein (isolated from Magnetospirillum sp. AMB-1) were required for biomagnetic nanoparticle formation. Magnetotactic bacteria (e.g. M. magnetotacticum and M. gryphiswaldense), contain magnetosome membrane (MM) proteins which play an important role in magnetite biomineralization. Thus, researchers have focused on identification of these proteins and their genes $[155,156]$. Recent molecular studies including genome sequence, mutagenesis, gene expression, and proteome analyses indicated a number of genes and proteins which play critical roles for bacterial magnetic particles biomineralization [157]. Moisescu et al. [158] have studied the chemical composition and microstructural characteristics of bacterial magnetosomes extracted from the magnetotactic bacterial strain M. gryphiswaldense. They reported the produced cuboctahedral magnetite particles with an average diameter of $46 \pm 6.8 \mathrm{~nm}$. The particles exhibited a high chemical purity (exclusively $\mathrm{Fe}_{3} \mathrm{O}_{4}$ ) and the majorities fall within the single-magnetic-domain range.

In cases of Rhodopseudomonas capsulata and Stenotrophomonas maltophilia, the authors believed that the specific $\mathrm{NADPH}$-dependent enzyme present in the isolated strains reduced $\mathrm{Au}^{+3}$ to $\mathrm{Au}^{0}$ through an electron shuttling mechanism, leading to the synthesis of monodispersed NPs. A twostep process is needed to reduce gold ions. During the first step, the $\mathrm{AuCl}_{4}{ }^{-}$ions are reduced to the $\mathrm{Au}^{+}$species. Then, the latter product is reduced by NADHP to a metallic gold $[77,78]$.

Mechanisms of gold accumulation by the cyanobacteria studied from gold chloride initially promoted the precipitation of amorphous gold sulfide at the cell walls and finally deposited metallic gold in octahedral form near the cell surfaces and in solutions [43]. Moreover, it was reported that the formation of gold NPs by Plectonema boryanum UTEX 485 occurred by three possible mechanisms involving iron sulfide, localized reducing conditions, and metabolism [148]. Lengke et al. [118] biosynthesized spherical platinum NPs using cyanobacterium, P. boryanum UTEX 485. The addition of $\mathrm{PtCl} 4^{0}$ to the bacterial culture initially promoted 
the precipitation of $\mathrm{Pt}^{+2}$-organic metal as spherical NPs in the solution, which then dispersed within the bacterial cells. The cyanobacteria were immediately killed either by the $\mathrm{PtCl} 4^{0}$, by the acidic $\mathrm{pH}$, or by the elevated temperatures $\left(\sim 60-180^{\circ} \mathrm{C}\right)$; the resulting release of organics caused further precipitation of platinum. With an increase in temperature, the $\mathrm{Pt}^{2}$-organic NPs were recrystallized and formed NPs consisting of a platinum metal. Riddin et al. [159] reported the bioreduction of $\mathrm{Pt}^{+4}$ into the $\mathrm{Pt}^{0}$ NPs. A mixed and uncharacterized consortium of sulphate-reducing bacteria was used to investigate the mechanism in the platinum nanoparticle formation. It was shown that two different hydrogenase enzymes were involved. First, the $\mathrm{Pt}^{+4}$ ions were reduced to $\mathrm{Pt}^{+2}$ by an oxygen-sensitive cytoplasmic hydrogenase. Then, the formed ions were reduced to $\mathrm{Pt}^{0} \mathrm{NPs}$ by a periplasmic hydrogenase that was oxygen tolerant and was inhibited by $\mathrm{Cu}^{+2}$.

To control the morphologies and sizes of NPs, there were several investigations focused on using proteins. Interestingly, association of proteins with spheroidal aggregates of biogenic zinc sulfide nanocrystals documented that extracellular proteins originated from microorganisms could limit the biogenic NPs [160]. Controlled formation of magnetite crystals with uniformed size was achieved in the presence of Mms6 (a small acidic protein isolated from Magnetospirillum magneticum AMB-1) [161]. The average size of magnetite crystals synthesized in the presence of Mms6 was about $20.2+4.0 \mathrm{~nm}$. But in the absence of Mms6, the synthesized magnetite crystals were about $32.4+9.1 \mathrm{~nm}$. Therefore, the crystals synthesized with Mms6 were smaller than crystals produced without Mms6 and were distributed over a narrower range than crystals synthesized in the absence of the protein. Mms6 also promoted formation of uniform, isomorphic, superparamagnetic nanocrystals [162]. With a bioinspired method, Prozorov et al. [163] have reported the use of the recombinant Mms6 protein for synthesis of uniform, well-defined $\mathrm{CoFe}_{2} \mathrm{O}_{4}$ nanocrystals in vitro. In order to template hierarchical $\mathrm{CoFe}_{2} \mathrm{O}_{4}$ nanostructures, a recombinant polyhistidine-tagged full-length Mms6 protein and a synthetic C-terminal domain of this protein were covalently attached to triblock copolymers (poloxamers).

In case of Klebsiella pneumoniae, it was reported that no formation of silver NPs by the supernatant was observed when the procedure took place in the dark. The visiblelight emission can significantly cause the synthesis of NPs. It seems that in this case, the silver ions reduction was mainly due to conjugation shuttles with the participation of the reductase. Thus, it appears that the cell-associated nitroreductase enzymes may be involved in the photoreduction of silver ions [164]. In addition, mechanisms of cadmium sulfide nanocrystals synthesis by $E$. coli cells were explained through the control experiments (incubation of $\mathrm{CdCl}_{2}$ and $\mathrm{Na}_{2} \mathrm{~S}$ without bacterial cells) which indicated that nanocrystals were not synthesized outside the cells and then transported into the cells [30]. These experiments have shown that CdS nanocrystals could be synthesized following $\mathrm{Cd}^{2+}$ and $\mathrm{S}^{2-}$ ions transported into the cells. In case of zinc sulfide $(\mathrm{ZnS})$, the NPs could be formed intracellularly through the biological synthetic method suggested by Bai et al. [48]. They explained that soluble sulfate diffused into immobilized beads and then was carried to the interior membrane of $R$. sphaeroides cell facilitated by sulfate permease. After that, ATP sulfurylase and phosphoadenosine phosphosulfate reductase reduced sulfate to sulfite, and sulfite reductase reduced sulfite to sulfide which reacted with $\mathrm{O}$ acetylserine to synthesize cysteine via $\mathrm{O}$-acetylserine thiol lyase. Then, cysteine produced $\mathrm{S}^{2-}$ by a cysteine desulfhydrase in presence of zinc. After this process, spherical ZnS NPs were synthesized following the reaction of $\mathrm{S}^{2-}$ with the soluble zinc salt. These NPs were discharged from immobilized $R$. sphaeroides cells to the solution.

\section{Future Prospects}

Major drawbacks associated with the biosynthesis of NPs using bacteria are tedious purification steps and poor understanding of the mechanisms. The important challenges frequently encountered in the biosynthesis of NPs are to control the shape and size of the particles and to achieve the monodispersity in solution phase. It seems that several important technical challenges must be overcome before this green bio-based method will be a successful and competitive alternative for industrial synthesis of NPs. An important challenge is scaling up for production level processing. Furthermore, little is known about the mechanistic aspects, and information in this regard is necessary for economic and rational development of nanoparticle biosynthesis. The important aspects which might be considered in the process of producing well-characterized NPs are as follows.

(1) Selection of the best bacteria. In order to choose the best candidates, researchers have focused on some important intrinsic properties of the bacteria including growth rate, enzyme activities, and biochemical pathways. Choosing a good candidate for nanoparticle production depends on the application we expect from the resulting NPs. For instance, one may need to synthesis NPs with smaller sizes or specific shapes, or it might be important to synthesize NPs within less time $[6,11]$.

(2) Selection of the biocatalyst state. It seems that the bacterial enzymes (the biocatalysts) are the major agents in nanoparticle synthesis. The biocatalysts can be used as either of whole cells, crude enzymes, and purified enzymes. It seems that using culture supernatant or cell extract of the cell could increase the rate of reaction. However these NPs did not show the long term stability. Moreover, release of NPs from the cells was an important aspect which might be considered in case of intracellularly produced NPs. Most of the reactions responsible for nanoparticle synthesis seem to be bioreductions. In bioreduction processes, we need the coenzymes (e.g., NADH, $\mathrm{NADPH}, \mathrm{FAD}$, etc.) to be supplied in stoichiometric amounts. As they are expensive, the use of whole cells is preferred, because the coenzymes will be recycled during the pathways in live whole cells [11]. 
(3) Optimal conditions for cell growth and enzyme activity. We need to produce greater amounts of the enzymes which can be accomplished by synthesis of more biomass. Thus, optimization of the growth conditions is very important. The nutrients, inoculum size, $\mathrm{pH}$, light, temperature, buffer strength, and mixing speed should be optimized. Induction of the responsible enzymes seems to be crucial, as well. The presence of the substrates or related compounds in subtoxic levels from the beginning of the growth would increase the activity. Harvesting time is important in case of using whole cells and crude enzymes. Therefore, it might be necessary to monitor the enzyme activity during the time course of growth [11].

(4) Optimal reaction conditions. It is better to harvest the cells (the biocatalysts) to remove unwanted residual nutrients and metabolites in order to avoid adverse reactions and provide cleaner medium for better and easier analysis. In order to use bacteria for synthesis of nanoparticle in industrial scale, the yield and the production rate are important issues to be considered. Therefore, we need to optimize the bioreduction conditions in the reaction mixture. The substrate concentration (to be in subtoxic level for the biocatalyst), the biocatalyst concentration, the electron donor (and its concentration), exposure time, $\mathrm{pH}$, temperature, buffer strength, mixing speed, and light need to be optimized. The researchers have used some complementary factors such as visible light or microwave irradiation and boiling which could affect the morphology, size, and rate of reaction. It seems that by optimization of these critical parameters, highly stable NPs with desired sizes and morphologies can be achieved. In addition, purification, isolation, and stabilization of the produced NPs are very important, and challenges in this regard must be overcome. Researchers have focused their attention on finding optimal reaction conditions and cellular mechanisms involved in the bioreduction of metal ions and synthesis of NPs [6-12, 165].

(5) Extraction and purification processes. The extraction and purification of the produced metal NPs from bacteria (intercellular or extracellular synthesis) for further applications are not well investigated, but studies are moving toward solving these problems and finding the best ways. In order to release the intracellularly produced NPs, additional processing steps such as ultrasound treatment or reaction with suitable detergents are required. This can be exploited in the recovery of precious metals from mine wastes and metal leachates. Biomatrixed metal NPs could also be used as catalysts in various chemical reactions. This will help to retain the NPs for continuous usage in bioreactors. Physicochemical methods including freeze-thawing, heating processes, and osmotic shock can be used to extract the produced NPs from the cells. But, it seems that these methods may interfere with the structure of NPs, and aggregation, precipitation, and sedimentation could happen. These may change the shape and size of NPs and interfere with the suitable properties of them. Moreover, enzymatic lysis of the microbial cells containing intracellular NPs can be used, but this method is expensive and it cannot be used in up-scalable and industrial production of NPs. It seems that surfactants and organic solvents can be used for both extraction and stabilization of NPs, but these chemical materials are toxic, expensive, and hazardous. It should be noted that in case of extracellular production of nanoparticle, centrifuge could be used for extraction and purification of NPs, but aggregation might happen.

(6) Stabilization of the produced NPs. Researchers have illustrated that the NPs produced by these ecofriendly bio-based approaches, showed an interesting stability without any aggregations even for many weeks in room temperature $[19,166]$. The stability of these NPs might be due to the proteins and enzymes secreted by the microorganisms. Thus, it seems that these green approaches can be used for synthesis of highly stable NPs.

(7) Scaling up the laboratory process to the industrial scale. Optimization of the reaction conditions may lead to the enhanced biosynthesis of NPs. Biological protocols could be used for synthesis of highly stable and well-characterized NPs when critical aspects, such as types of organisms, inheritable and genetical properties of organisms, optimal conditions for cell growth and enzyme activity, optimal reaction conditions, and selection of the biocatalyst state have been considered. Size and morphology of the NPs can be controlled by altering the aforementioned reaction conditions (optimal reaction conditions section). Industrial scale synthesis of metal NPs using biomass needs some processes, including seed culture, inoculation of the seed into the biomass, harvesting the cells, synthesis of NPs by adding metal ions to the cells, separation of cells by filtration, homogenization of the cells to isolate the produced NPs, stabilization of the NPs, product formulation, and quality control $[6-12,165]$.

\section{Conclusion}

Bio-based approaches are still in the development stages, and stability and aggregation of the biosynthesized NPs, control of crystal growth, shape, size, and size distribution are the most important experienced problems. Furthermore, biologically synthesized NPs in comparison with chemically synthesized ones are more polydisperse. The properties of NPs can be controlled by optimization of important parameters which control the growth condition of organisms, cellular activities, and enzymatic processes (optimization of growth and reaction conditions).

Mechanistic aspects have not been clearly and deeply described and discussed. Thus, more elaborated studies are needed to know the exact mechanisms of reaction and 
identify the enzymes and proteins which involve nanoparticle biosynthesis. The large-scale synthesis of NPs using bacteria is interesting because it does not need any hazardous, toxic, and expensive chemical materials for synthesis and stabilization processes. It seems that by optimizing the reaction conditions and selecting the best bacteria, these natural nanofactories can be used in the synthesis of stable NPs with well-defined sizes, morphologies, and compositions.

\section{Conflict of Interests}

The author declares that there is no conflict of interests regarding the publication of this paper.

\section{Acknowledgment}

This review was supported by Faculty of Pharmacy and Pharmaceutical Sciences, Isfahan University of Medical Sciences.

\section{References}

[1] D. Bhattacharya and R. K. Gupta, "Nanotechnology and potential of microorganisms," Critical Reviews in Biotechnology, vol. 25, no. 4, pp. 199-204, 2005.

[2] D. Goodsell, Bionanotechnology: Lessons from Nature, WilleyLess, New Jersey, NJ, USA, 2004.

[3] R. Paull, J. Wolfe, P. Hébert, and M. Sinkula, "Investing in nanotechnology," Nature Biotechnology, vol. 21, no. 10, pp. 11441147, 2003.

[4] O. V. Salata, "Applications of nanoparticles in biology and medicine," Journal of Nanobiotechnology, vol. 2, no. 1, article 3, 2004.

[5] M. Sastry, A. Ahmad, M. Islam Khan, and R. Kumar, "Biosynthesis of metal nanoparticles using fungi and actinomycete," Current Science, vol. 85, no. 2, pp. 162-170, 2003.

[6] S. Iravani, "Green synthesis of metal nanoparticles using plants," Green Chemistry, vol. 13, no. 10, pp. 2638-2650, 2011.

[7] S. Iravani, H. Korbekandi, S. V. Mirmohammadi, and H. Mekanik, "Plants in nanoparticle synthesis," Reviews in Advanced Sciences and Engineering, vol. 3, no. 3, pp. 261-274, 2014.

[8] S. Iravani and B. Zolfaghari, "Green synthesis of silver nanoparticles using Pinus eldarica bark extract," Biomed Research International, vol. 2013, Article ID 639725, 5 pages, 2013.

[9] H. Korbekandi, Z. Ashari, S. Iravani, and S. Abbasi, "Optimization of biological synthesis of silver nanoparticles using Fusarium oxysporum," Iranian Journal of Pharmaceutical Research, vol. 12, no. 3, pp. 289-298, 2013.

[10] H. Korbekandi and S. Iravani, "Biological synthesis of nanoparticles using algae," in Green Biosynthesis of Nanoparticles: Mechanisms and Applications, M. Rai and C. Posten, Eds., pp. 53-60, CABI, Wallingford, UK, 2013.

[11] H. Korbekandi, S. Iravani, and S. Abbasi, "Production of nanoparticles using organisms," Critical Reviews in Biotechnology, vol. 29, no. 4, pp. 279-306, 2009.

[12] H. Korbekandi, S. Iravani, and S. Abbasi, "Optimization of biological synthesis of silver nanoparticles using Lactobacillus casei subsp. casei," Journal of Chemical Technology \& Biotechnology, vol. 87, no. 7, pp. 932-937, 2012.
[13] T. Klaus-Joerger, R. Joerger, E. Olsson, and C. Granqvist, "Bacteria as workers in the living factory: metal-accumulating bacteria and their potential for materials science," Trends in Biotechnology, vol. 19, no. 1, pp. 15-20, 2001.

[14] M. D. Mullen, D. C. Wolf, F. G. Ferris, T. J. Beveridge, C. A. Flemming, and G. W. Bailey, "Bacterial sorption of heavy metals," Applied and Environmental Microbiology, vol. 55, no. 12, pp. 3143-3149, 1989.

[15] S. He, Z. Guo, Y. Zhang, S. Zhang, J. Wang, and N. Gu, "Biosynthesis of gold nanoparticles using the bacteria Rhodopseudomonas capsulata," Materials Letters, vol. 61, no. 18, pp. 39843987, 2007.

[16] M. F. Lengke, M. E. Fleet, and G. Southam, "Biosynthesis of silver nanoparticles by filamentous cyanobacteria from a silver(I) nitrate complex," Langmuir, vol. 23, no. 5, pp. 26942699, 2007.

[17] A. Rai, A. Singh, A. Ahmad, and M. Sastry, "Role of halide ions and temperature on the morphology of biologically synthesized gold nanotriangles," Langmuir, vol. 22, no. 2, pp. 736-741, 2006.

[18] S. Sunkar and C. V. Nachiyar, "Biogenesis of antibacterial silver nanoparticles using the endophytic bacterium Bacillus cereus isolated from Garcinia xanthochymus," Asian Pacific Journal of Tropical Biomedicine, vol. 2, no. 12, pp. 953-959, 2012.

[19] L. Wen, Z. Lin, P. Gu et al., "Extracellular biosynthesis of monodispersed gold nanoparticles by a SAM capping route," Journal of Nanoparticle Research, vol. 11, no. 2, pp. 279-288, 2009.

[20] T. J. Beveridge and R. G. E. Murray, "Sites of metal deposition in the cell wall of Bacillus subtilis," Journal of Bacteriology, vol. 141, no. 2, pp. 876-887, 1980.

[21] G. Southam and T. J. Beveridge, "The in vitro formation of placer gold by bacteria," Geochimica et Cosmochimica Acta, vol. 58, no. 20, pp. 4527-4530, 1994.

[22] N. Saifuddin, C. W. Wong, and A. A. N. Yasumira, "Rapid biosynthesis of silver nanoparticles using culture supernatant of bacteria with microwave irradiation," E-Journal of Chemistry, vol. 6, no. 1, pp. 61-70, 2009.

[23] D. P. Cunningham and L. L. Lundie Jr., "Precipitation of cadmium by Clostridium thermoaceticum," Applied and Environmental Microbiology, vol. 59, no. 1, pp. 7-14, 1993.

[24] H. R. Zhang, Q. B. Li, Y. H. Lu et al., "Biosorption and bioreduction of diamine silver complex by Corynebacterium," Journal of Chemical Technology and Biotechnology, vol. 80, no. 3, pp. 285-290, 2005.

[25] M. Labrenz, G. K. Druschel, T. Thomsen-Ebert et al., "Formation of sphalerite $(\mathrm{ZnS})$ deposits in natural biofilms of sulfatereducing bacteria," Science, vol. 290, no. 5497, pp. 1744-1747, 2000.

[26] J. Kessi, M. Ramuz, E. Wehrli, M. Spycher, and R. Bachofen, "Reduction of selenite and detoxification of elemental selenium by the phototrophic bacterium Rhodospirillum rubrum," Applied and Environmental Microbiology, vol. 65, no. 11, pp. 4734-4740, 1999.

[27] P. Yong, N. A. Rowson, J. P. G. Farr, I. R. Harris, and L. E. Macaskie, "Bioreduction and biocrystallization of palladium by Desulfovibrio desulfuricans NCIMB 8307," Biotechnology and Bioengineering, vol. 80, no. 4, pp. 369-379, 2002.

[28] K. Kashefi, J. M. Tor, K. P. Nevin, and D. R. Lovley, "Reductive precipitation of gold by dissimilatory Fe(III)-reducing bacteria and archaea," Applied and Environmental Microbiology, vol. 67, no. 7, pp. 3275-3279, 2001. 
[29] M. Pósfai, B. M. Moskowitz, B. Arató et al., "Properties of intracellular magnetite crystals produced by Desulfovibrio magneticus strain RS-1," Earth and Planetary Science Letters, vol. 249, no. 3-4, pp. 444-455, 2006.

[30] R. Y. Sweeney, C. Mao, X. Gao et al., "Bacterial biosynthesis of cadmium sulfide nanocrystals," Chemistry and Biology, vol. 11, no. 11, pp. 1553-1559, 2004.

[31] A. Mahanty, R. Bosu, P. Panda, S. P. Netam, and B. Sarkar, "Microwave assisted rapid combinatorial synthesis of silver nanoparticles using E. coli culture supernatant," International Journal of Pharma and Bio Sciences, vol. 4, no. 2, pp. 1030-1035, 2013.

[32] H. R. Ghorbani, "Biosynthesis of silver nanoparticles by Escherichia coli," Asian Journal of Chemistry, vol. 25, no. 3, pp. 1247-1249, 2013.

[33] L. Du, H. Jiang, X. Liu, and E. Wang, "Biosynthesis of gold nanoparticles assisted by Escherichia coli DH5 $\alpha$ and its application on direct electrochemistry of hemoglobin," Electrochemistry Communications, vol. 9, no. 5, pp. 1165-1170, 2007.

[34] K. Deplanche and L. E. Macaskie, "Biorecovery of gold by Escherichia coli and Desulfovibrio desulfuricans," Biotechnology and Bioengineering, vol. 99, no. 5, pp. 1055-1064, 2008.

[35] D. N. Correa-Llantén, S. A. Muñoz-Ibacache, M. E. Castro, P. A. Muñoz, and J. M. Blamey, "Gold nanoparticles synthesized by Geobacillus sp. strain ID17 a thermophilic bacterium isolated from Deception Island, Antarctica," Microbial Cell Factories, vol. 12, no. 1, article 75, 2013.

[36] J. D. Holmes, P. R. Smith, R. Evans-Gowing, D. J. Richardson, D. A. Russell, and J. R. Sodeau, "Energy-dispersive X-ray analysis of the extracellular cadmium sulfide crystallites of Klebsiella aerogenes," Archives of Microbiology, vol. 163, no. 2, pp. 143-147, 1995.

[37] A. R. Shahverdi, S. Minaeian, H. R. Shahverdi, H. Jamalifar, and A. Nohi, "Rapid synthesis of silver nanoparticles using culture supernatants of Enterobacteria: a novel biological approach," Process Biochemistry, vol. 42, no. 5, pp. 919-923, 2007.

[38] B. Nair and T. Pradeep, "Coalescence of nanoclusters and formation of submicron crystallites assisted by Lactobacillus strains," Crystal Growth and Design, vol. 2, no. 4, pp. 293-298, 2002.

[39] K. Prasad, A. K. Jha, and A. R. Kulkarni, "Lactobacillus assisted synthesis of titanium nanoparticles," Nanoscale Research Letters, vol. 2, no. 5, pp. 248-250, 2007.

[40] A. P. Philipse and D. Maas, "Magnetic colloids from magnetotactic bacteria: chain formation and colloidal stability," Langmuir, vol. 18, no. 25, pp. 9977-9984, 2002.

[41] P. Manivasagan, J. Venkatesan, K. Senthilkumar, K. Sivakumar, and S. Kim, "Biosynthesis, antimicrobial and cytotoxic effect of silver nanoparticles using a novel Nocardiopsis sp. MBRC-1," BioMed Research International, vol. 2013, Article ID 287638, 9 pages, 2013.

[42] M. F. Lengke, M. E. Fleet, and G. Southam, "Morphology of gold nanoparticles synthesized by filamentous cyanobacteria from gold(I)-Thiosulfate and gold(III)-chloride complexes," Langmuir, vol. 22, no. 6, pp. 2780-2787, 2006.

[43] M. F. Lengke, B. Ravel, M. E. Fleet, G. Wanger, R. A. Gordon, and G. Southam, "Mechanisms of gold bioaccumulation by filamentous cyanobacteria from gold(III)-chloride complex," Environmental Science and Technology, vol. 40, no. 20, pp. 63046309, 2006.

[44] M. I. Husseiny, M. A. El-Aziz, Y. Badr, and M. A. Mahmoud, "Biosynthesis of gold nanoparticles using Pseudomonas aeruginosa," Spectrochimica Acta A: Molecular and Biomolecular Spectroscopy, vol. 67, no. 3-4, pp. 1003-1006, 2007.

[45] S. R. Rajasree and T. Y. Suman, "Extracellular biosynthesis of gold nanoparticles using a gram negative bacterium Pseudomonas fluorescens," Asian Pacific Journal of Tropical Disease, vol. 2, no. 2, pp. S796-S799, 2012.

[46] V. Thamilselvi and K. V. Radha, "Synthesis of silver nanoparticles from Pseudomonas putida NCIM 2650 in silver nitrate supplemented growth medium and optimization using response surface methodology," Digest Journal of Nanomaterials and Biostructures, vol. 8, no. 3, pp. 1101-1111, 2013.

[47] C. Haefeli, C. Franklin, and K. Hardy, "Plasmid-determined silver resistance in Pseudomonas stutzeri isolated from a silver mine," Journal of Bacteriology, vol. 158, no. 1, pp. 389-392, 1984.

[48] H. Bai, Z. Zhang, and J. Gong, "Biological synthesis of semiconductor zinc sulfide nanoparticles by immobilized Rhodobacter sphaeroides," Biotechnology Letters, vol. 28, no. 14, pp. 1135-1139, 2006.

[49] S. He, Y. Zhang, Z. Guo, and N. Gu, "Biological synthesis of gold nanowires using extract of Rhodopseudomonas capsulata," Biotechnology Progress, vol. 24, no. 2, pp. 476-480, 2008.

[50] H. J. Bai, Z. M. Zhang, Y. Guo, and G. E. Yang, "Biosynthesis of cadmium sulfide nanoparticles by photosynthetic bacteria Rhodopseudomonas palustris," Colloids and Surfaces B: Biointerfaces, vol. 70, no. 1, pp. 142-146, 2009.

[51] C. Malarkodi, S. Rajeshkumar, K. Paulkumar, M. Vanaja, G. D. G. Jobitha, and G. Annadurai, "Bactericidal activity of bio mediated silver nanoparticles synthesized by Serratia nematodiphila," Drug Invention Today, vol. 5, no. 2, pp. 119-125, 2013.

[52] Y. Konishi, K. Ohno, N. Saitoh et al., "Bioreductive deposition of platinum nanoparticles on the bacterium Shewanella algae," Journal of Biotechnology, vol. 128, no. 3, pp. 648-653, 2007.

[53] D. R. Lovley, J. F. Stolz, G. L. Nord Jr., and E. J. P. Phillips, "Anaerobic production of magnetite by a dissimilatory ironreducing microorganism," Nature, vol. 330 , no. 6145, pp. 252254, 1987.

[54] L. W. Yeary, J. Moon, L. J. Love, J. R. Thompson, C. J. Rawn, and T. J. Phelps, "Magnetic properties of biosynthesized magnetite nanoparticles," IEEE Transactions on Magnetics, vol. 41, no. 12, pp. 4384-4389, 2005.

[55] K. Bridges, A. Kidson, E. J. L. Lowbury, and M. D. Wilkins, "Gentamicin- and silver-resistant Pseudomonas in a burns unit," British Medical Journal, vol. 1, no. 6161, pp. 446-449, 1979.

[56] T. D. Brock and J. Gustafson, "Ferric iron reduction by sulfur- and iron-oxidizing bacteria.," Applied and Environmental Microbiology, vol. 32, no. 4, pp. 567-571, 1976.

[57] D. E. Taylor, "Bacterial tellurite resistance," Trends in Microbiology, vol. 7, no. 3, pp. 111-115, 1999.

[58] J. R. Lloyd, J. Ridley, T. Khizniak, N. N. Lyalikova, and L. E. Macaskie, "Reduction of technetium by Desulfovibrio desulfuricans: biocatalyst characterization and use in a flowthrough bioreactor," Applied and Environmental Microbiology, vol. 65, no. 6, pp. 2691-2696, 1999.

[59] K. Kalishwaralal, V. Deepak, S. Ramkumarpandian, H. Nellaiah, and G. Sangiliyandi, "Extracellular biosynthesis of silver nanoparticles by the culture supernatant of Bacillus licheniformis," Materials Letters, vol. 62, no. 29, pp. 4411-4413, 2008.

[60] K. Kalimuthu, R. Suresh Babu, D. Venkataraman, M. Bilal, and S. Gurunathan, "Biosynthesis of silver nanocrystals by Bacillus licheniformis," Colloids and Surfaces B: Biointerfaces, vol. 65, no. 1, pp. 150-153, 2008. 
[61] S. Priyadarshini, V. Gopinath, N. Meera Priyadharsshini, D. MubarakAli, and P. Velusamy, "Synthesis of anisotropic silver nanoparticles using novel strain, Bacillus flexus and its biomedical application," Colloids and Surfaces B: Biointerfaces, vol. 102, pp. 232-237, 2013.

[62] X. Wei, M. Luo, W. Li et al., "Synthesis of silver nanoparticles by solar irradiation of cell-free Bacillus amyloliquefaciens extracts and $\mathrm{AgNO}_{3}$," Bioresource Technology, vol. 103, no. 1, pp. 273-278, 2012.

[63] R. M. Slawson, M. I. Van Dyke, H. Lee, and J. T. Trevors, "Germanium and silver resistance, accumulation, and toxicity in microorganisms," Plasmid, vol. 27, no. 1, pp. 73-79, 1992.

[64] T. Klaus, R. Joerger, E. Olsson, and C. Granqvist, "Silver-based crystalline nanoparticles, microbially fabricated," Proceedings of the National Academy of Sciences of the United States of America, vol. 96, no. 24, pp. 13611-13614, 1999.

[65] S. Shivaji, S. Madhu, and S. Singh, "Extracellular synthesis of antibacterial silver nanoparticles using psychrophilic bacteria," Process Biochemistry, vol. 46, no. 9, pp. 1800-1807, 2011.

[66] D. R. Lovley, "Dissimilatory Fe(III) and Mn(IV) reduction," Microbiological Reviews, vol. 55, no. 2, pp. 259-287, 1991.

[67] A. K. Suresh, D. A. Pelletier, W. Wang et al., "Silver nanocrystallites: biofabrication using shewanella oneidensis, and an evaluation of their comparative toxicity on gram-negative and gram-positive bacteria," Environmental Science and Technology, vol. 44, no. 13, pp. 5210-5215, 2010.

[68] N. Mokhtari, S. Daneshpajouh, S. Seyedbagheri et al., "Biological synthesis of very small silver nanoparticles by culture supernatant of Klebsiella pneumonia: the effects of visible-light irradiation and the liquid mixing process," Materials Research Bulletin, vol. 44, no. 6, pp. 1415-1421, 2009.

[69] M. Fu, Q. Li, D. Sun et al., "Rapid preparation process of silver nanoparticles by bioreduction and their characterizations," Chinese Journal of Chemical Engineering, vol. 14, no. 1, pp. 114$117,2006$.

[70] S. Kapoor, "Preparation, characterization, and surface modification of silver particles," Langmuir, vol. 14, no. 5, pp. 1021-1025, 1998.

[71] R. A. Satyanarayana, C. Chen, J. Jean et al., "Biological synthesis of gold and silver nanoparticles mediated by the bacteria Bacillus subtilis," Journal of Nanoscience and Nanotechnology, vol. 10, no. 10, pp. 6567-6574, 2010.

[72] J. P. Bowman, S. A. McCammon, D. S. Nichols et al., "Shewanella gelidimarina sp. nov. and Shewanella frigidimarina sp. nov., novel antarctic species with the ability to produce eicosapentaenoic acid (20:5 $\omega 3)$ and grow anaerobically by dissimilatory fe(III) reduction," International Journal of Systematic Bacteriology, vol. 47, no. 4, pp. 1040-1047, 1997.

[73] N. Bozal, M. J. Montes, E. Tudela, F. Jiménez, and J. Guinea, "Shewanella frigidimarina and Shewanella livingstonensis sp. nov. isolated from Antarctic coastal areas," International Journal of Systematic and Evolutionary Microbiology, vol. 52, no. 1, pp. 195-205, 2002.

[74] E. P. Ivanova, T. Sawabe, N. M. Gorshkova et al., "Shewanella japonica sp. nov.", International Journal of Systematic and Evolutionary Microbiology, vol. 51, no. 3, pp. 1027-1033, 2001.

[75] E. P. Ivanova, O. I. Nedashkovskaya, N. V. Zhukova, D. V. Nicolau, R. Christen, and V. V. Mikhailov, "Shewanella waksmanii sp. nov., isolated from a sipunculla (Phascolosoma japonicum)," International Journal of Systematic and Evolutionary Microbiology, vol. 53, no. 5, pp. 1471-1477, 2003.
[76] E. P. Ivanova, T. Sawabe, K. Hayashi et al., "Shewanella fidelis sp. nov., isolated from sediments and sea water," International Journal of Systematic and Evolutionary Microbiology, vol. 53, no. 2, pp. 577-582, 2003.

[77] Y. Nogi, C. Kato, and K. Horikoshi, “Taxonomic studies of deepsea barophilic Shewanella strains and description of Shewanella violacea sp. nov.," Archives of Microbiology, vol. 170, no. 5, pp. 331-338, 1998.

[78] M. Satomi, H. Oikawa, and Y. Yano, "Shewanella marinintestina sp. nov., Shewanella schlegeliana sp. nov. and Shewanella sairae sp. nov., novel eicosapentaenic-acid-producing marine bacteria isolated from sea-animal intestines," International Journal of Systematic and Evolutionary Microbiology, vol. 53, no. 2, pp. 491499, 2003.

[79] K. Venkateswaran, D. P. Moser, M. E. Dollhopf et al., "Polyphasic taxonomy of the genus Shewanella and description of Shewanella oneidensis sp. nov.," International Journal of Systematic Bacteriology, vol. 49, no. 2, pp. 705-724, 1999.

[80] J. S. Zhao, D. Manno, C. Beaulieu, L. Paquet, and J. Hawari, "Shewanella sediminis sp. nov., a novel $\mathrm{Na}^{+}$- requiring and hexahydro-1,3,5-trinitro-1,3,5-triazine-degrading bacterium from marine sediment," International Journal of Systematic and Evolutionary Microbiology, vol. 55, no. 4, pp. 1511-1520, 2005.

[81] D. Kim, C. Kang, C. S. Lee et al., "Treatment failure due to emergence of resistance to carbapenem during therapy for Shewanella algae bacteremia," Journal of Clinical Microbiology, vol. 44, no. 3, pp. 1172-1174, 2006.

[82] Y. Konishi, T. Tsukiyama, T. Tachimi, N. Saitoh, T. Nomura, and S. Nagamine, "Microbial deposition of gold nanoparticles by the metal-reducing bacterium Shewanella algae," Electrochimica Acta, vol. 53, no. 1, pp. 186-192, 2007.

[83] F. Caccavo Jr., R. P. Blakemore, and D. R. Lovley, "A hydrogenoxidizing, $\mathrm{Fe}(\mathrm{III})$-reducing microorganism from the Great Bay estuary, New Hampshire," Applied and Environmental Microbiology, vol. 58, no. 10, pp. 3211-3216, 1992.

[84] Y. Konishi, T. Tsukiyama, K. Ohno, N. Saitoh, T. Nomura, and S. Nagamine, "Intracellular recovery of gold by microbial reduction of $\mathrm{AuCl}_{4}^{-}$ions using the anaerobic bacterium Shewanella algae," Hydrometallurgy, vol. 81, no. 1, pp. 24-29, 2006.

[85] L. M. Fernando, F. E. Merca, and E. S. Paterno, "Biogenic synthesis of gold nanoparticles by plant-growth-promoting bacteria isolated from philippine soils," Philippine Agricultural Scientist, vol. 96, no. 2, pp. 129-136, 2013.

[86] B. Arató, D. Schüler, C. Flies, D. Bazylinski, R. Frankel, and P. Buseck, "Intracellular magnetite and extracellular hematite produced by Desulfovibrio magneticus strain RS-1," Geophysical Research Abstracts, vol. 6, 2004.

[87] Y. Roh, R. J. Lauf, A. D. McMillan et al., "Microbial synthesis and the characterization of metal-substituted magnetites," Solid State Communications, vol. 118, no. 10, pp. 529-534, 2001.

[88] H. Lee, A. M. Purdon, V. Chu, and R. M. Westervelt, "Controlled assembly of magnetic nanoparticles from magnetotactic bacteria using microelectromagnets arrays," Nano Letters, vol. 4, no. 5, pp. 995-998, 2004.

[89] M. J. Baedecker and W. Back, "Modern marine sediments as a natural analog to the chemically stressed environment of a landfill," Journal of Hydrology, vol. 43, no. 1-4, pp. 393-414, 1979.

[90] D. Lovley, "Organic matter mineralization with the reduction of ferric iron," Geomicrobiology Journal, vol. 5, pp. 375-399, 1987.

[91] A. L. Graybeal and G. R. Heath, "Remobilization of transition metals in surficial pelagic sediments from the eastern Pacific," 
Geochimica et Cosmochimica Acta, vol. 48, no. 5, pp. 965-975, 1984.

[92] B. Bostrom, M. Jansson, and C. Forsberg, "Phosphorus release from lake sediments," Archiv für Hydrobiologie-Beiheft Ergebnisse der Limnologie, vol. 18, pp. 5-59, 1982.

[93] J. H. P. Watson, D. C. Ellwood, A. K. Soper, and J. Charnock, "Nanosized strongly-magnetic bacterially-produced iron sulfide materials," Journal of Magnetism and Magnetic Materials, vol. 203, no. 1-3, pp. 69-72, 1999.

[94] J. H. P. Watson, I. W. Croudace, P. E. Warwick, P. A. B. James, J. M. Charnock, and D. C. Ellwoods, "Adsorption of radioactive metals by strongly magnetic iron sulfide nanoparticles produced by sulfate-reducing bacteria," Separation Science and Technology, vol. 36, no. 12, pp. 2571-2607, 2001.

[95] D. R. Lovley and E. J. P. Phillips, "Novel mode of microbial energy metabolism: organic carbon oxidation coupled to dissimilatory reduction of iron or manganese," Applied \& Environmental Microbiology, vol. 54, no. 6, pp. 1472-1480, 1988.

[96] D. R. Lovley, E. J. P. Phillips, and D. J. Lonergan, "Hydrogen and formate oxidation coupled to dissimilatory reduction of iron or manganese by Alteromonas putrefaciens," Applied and Environmental Microbiology, vol. 55, no. 3, pp. 700-706, 1989.

[97] D. R. Lovley, E. J. P. Phillips, D. J. Lonergan, and P. K. Widman, "Fe(III) and S0 reduction by Pelobacter carbinolicus," Applied and Environmental Microbiology, vol. 61, no. 6, pp. 2132-2138, 1995.

[98] M. Jahn, S. Haderlein, and R. Meckenstock, "A novel mechanism of electron transfer from iron-reducing microorganisms to solid iron phases," Geophysical Research Abstracts, vol. 7, article 01998, 2005.

[99] E. E. Roden and D. R. Lovley, "Dissimilatory Fe(III) reduction by the marine microorganism Desulfuromonas acetoxidans," Applied and Environmental Microbiology, vol. 59, no. 3, pp. 734742, 1993.

[100] K. Kashefi and D. R. Lovley, "Reduction of Fe(III), Mn(IV), and toxic metals at $100^{\circ} \mathrm{C}$ by Pyrobaculum islandicum," Applied and Environmental Microbiology, vol. 66, no. 3, pp. 1050-1056, 2000.

[101] T. L. Kieft, J. K. Fredrickson, T. C. Onstott et al., "Dissimilatory reduction of $\mathrm{Fe}(\mathrm{III})$ and other electron acceptors by a thermus isolate," Applied and Environmental Microbiology, vol. 65, no. 3, pp. 1214-1221, 1999.

[102] S. V. Liu, J. Zhou, C. Zhang, D. R. Cole, M. GajdarziskaJosifovska, and T. J. Phelps, "Thermophilic Fe(III)-reducing bacteria from the deep subsurface: the evolutionary implications," Science, vol. 277, no. 5329, pp. 1106-1109, 1997.

[103] C. Zhang, S. Liu, J. Logan, R. Mazumder, and T. J. Phelps, "Enhancement of $\mathrm{Fe}(\mathrm{III}), \mathrm{Co}(\mathrm{III})$, and $\mathrm{Cr}(\mathrm{VI})$ reduction at elevated temperatures and by a thermophilic bacterium," Applied Biochemistry and Biotechnology A, vol. 57-58, pp. 923-932, 1996.

[104] A. Ahmad, S. Senapati, M. I. Khan, R. Kumar, and M. Sastry, "Extracellular biosynthesis of monodisperse gold nanoparticles by a novel extremophilic actinomycete, Thermomonospora sp.", Langmuir, vol. 19, no. 8, pp. 3550-3553, 2003.

[105] C. Zhang, H. Vali, C. S. Romaner, T. J. Phelps, and S. V. Liu, "Formation of single-domain magnetite by a thermophilic bacterium," The American Mineralogist, vol. 83, no. 11-12, pp. 1409-1418, 1998.

[106] A. M. Laverman, J. S. Blum, J. K. Schaefer, E. J. P. Phillips, D. R. Lovley, and R. S. Oremland, "Growth of strain SES-3 with arsenate and other diverse electron acceptors," Applied and Environmental Microbiology, vol. 61, no. 10, pp. 3556-3561, 1995.
[107] D. Lovley, "Fe (III) and Mn (IV) reduction," in Environmental Microbe-Metal Interactions, D. Lovley, Ed., pp. 3-30, ASM Press, Washington, DC, USA, 2000.

[108] R. Oremland, "Biogeochemical transformations of selenium in anoxic environments," in Selenium in the Environment, W. T. J. Frankenberger and S. Benson, Eds., pp. 389-419, Mareel Dekker, New York, NY, USA, 1994.

[109] D. L. J. Thorek, A. K. Chen, J. Czupryna, and A. Tsourkas, "Superparamagnetic iron oxide nanoparticle probes for molecular imaging," Annals of Biomedical Engineering, vol. 34, no. 1, pp. 23-38, 2006.

[110] W. J. Rogers and P. Basu, "Factors regulating macrophage endocytosis of nanoparticles: implications for targeted magnetic resonance plaque imaging," Atherosclerosis, vol. 178, no. 1, pp. 67-73, 2005.

[111] P. Moroz, S. K. Jones, and B. N. Gray, "Tumor response to arterial embolization hyperthermia and direct injection hyperthermia in a rabbit liver tumor model," Journal of Surgical Oncology, vol. 80, no. 3, pp. 149-156, 2002.

[112] P. Moroz, S. K. Jones, and B. N. Gray, "Magnetically mediated hyperthermia: current status and future directions," International Journal of Hyperthermia, vol. 18, no. 4, pp. 267-284, 2002.

[113] L. J. Love, J. F. Jansen, T. E. McKnight et al., "Ferrofluid field induced flow for microfluidic applications," IEEE/ASME Transactions on Mechatronics, vol. 10, no. 1, pp. 68-76, 2005.

[114] L. J. Love, J. F. Jansen, T. E. McKnight, Y. Roh, and T. J. Phelps, "A magnetocaloric pump for microfluidic applications," IEEE Transactions on Nanobioscience, vol. 3, no. 2, pp. 101-110, 2004.

[115] J. R. Lloyd, P. Yong, and L. E. Macaskie, "Enzymatic recovery of elemental palladium by using sulfate-reducing bacteria," Applied and Environmental Microbiology, vol. 64, no. 11, pp. 4607-4609, 1998.

[116] W. de Windt, P. Aelterman, and W. Verstraete, "Bioreductive deposition of palladium (0) nanoparticles on Shewanella oneidensis with catalytic activity towards reductive dechlorination of polychlorinated biphenyls," Environmental Microbiology, vol. 7, no. 3, pp. 314-325, 2005.

[117] P. Yong, N. A. Rowson, J. P. G. Farr, I. R. Harris, and L. Macaskie, "Bioaccumulation of palladium by Desulfovibrio desulfuricans," Journal of Chemical Technology and Biotechnology, vol. 77, pp. 593-601, 2002.

[118] M. F. Lengke, M. E. Fleet, and G. Southam, "Synthesis of platinum nanoparticles by reaction of filamentous cyanobacteria with platinum(IV)-chloride complex," Langmuir, vol. 22, no. 17, pp. 7318-7323, 2006.

[119] K. B. Narayanan and N. Sakthivel, "Biological synthesis of metal nanoparticles by microbes," Advances in Colloid and Interface Science, vol. 156, no. 1-2, pp. 1-13, 2010.

[120] W. J. Hunter and D. K. Manter, "Bio-reduction of selenite to elemental red selenium by Tetrathiobacter kashmirensis," Current Microbiology, vol. 57, no. 1, pp. 83-88, 2008.

[121] V. Yadav, N. Sharma, R. Prakash, K. K. Raina, L. M. Bharadwaj, and N. T. Prakash, "Generation of selenium containing nanostructures by soil bacterium, Pseudomonas aeruginosa," Biotechnology, vol. 7, no. 2, pp. 299-304, 2008.

[122] R. S. Oremland, M. J. Herbel, J. S. Blum et al., "Structural and spectral features of selenium nanospheres produced by Serespiring bacteria," Applied and Environmental Microbiology, vol. 70, no. 1, pp. 52-60, 2004.

[123] S. Dwivedi, A. A. AlKhedhairy, M. Ahamed, and J. Musarrat, "Biomimetic synthesis of selenium nanospheres by bacterial 
strain JS-11 and its role as a biosensor for nanotoxicity assessment: a novel se-bioassay," PLoS ONE, vol. 8, no. 3, Article ID e57404, 2013.

[124] S. M. Baesman, T. D. Bullen, J. Dewald et al., "Formation of tellurium nanocrystals during anaerobic growth of bacteria that use Te oxyanions as respiratory electron acceptors," Applied and Environmental Microbiology, vol. 73, no. 7, pp. 2135-2143, 2007.

[125] B. Zare, M. A. Faramarzi, Z. Sepehrizadeh, M. Shakibaie, S. Rezaie, and A. R. Shahverdi, "Biosynthesis and recovery of rodshaped tellurium nanoparticles and their bactericidal activities," Materials Research Bulletin, vol. 47, no. 11, pp. 3719-3725, 2012.

[126] C. Jayaseelan, A. A. Rahuman, A. V. Kirthi et al., "Novel microbial route to synthesize $\mathrm{ZnO}$ nanoparticles using Aeromonas hydrophila and their activity against pathogenic bacteria and fungi," Spectrochimica Acta A: Molecular and Biomolecular Spectroscopy, vol. 90, pp. 78-84, 2012.

[127] S. Babitha and P. S. Korrapati, "Biosynthesis of titanium dioxide nanoparticles using a probiotic from coal fly ash effluent," Materials Research Bulletin, vol. 48, pp. 4738-4742, 2013.

[128] A. Vishnu Kirthi, A. Abdul Rahuman, G. Rajakumar et al., "Biosynthesis of titanium dioxide nanoparticles using bacterium Bacillus subtilis," Materials Letters, vol. 65, no. 17-18, pp. 2745-2747, 2011.

[129] C. T. Dameron, R. N. Reese, R. K. Mehra et al., "Biosynthesis of cadmium sulphide quantum semiconductor crystallites," Nature, vol. 338, no. 6216, pp. 596-597, 1989.

[130] P. Williams, E. Keshavarz-Moore, and P. Dunnill, "Production of cadmium sulphide microcrystallites in batch cultivation by Schizosaccharomyces pombe," Journal of Biotechnology, vol. 48, no. 3, pp. 259-267, 1996.

[131] W. C. W. Chan, D. J. Maxwell, X. Gao, R. E. Bailey, M. Han, and S. Nie, "Luminescent quantum dots for multiplexed biological detection and imaging," Current Opinion in Biotechnology, vol. 13, no. 1, pp. 40-46, 2002.

[132] D. P. Barondeau and P. A. Lindahl, "Methylation of carbon monoxide dehydrogenase from Clostridium thermoaceticum and mechanism of acetyl coenzyme A synthesis," Journal of the American Chemical Society, vol. 119, no. 17, pp. 3959-3970, 1997.

[133] H. Bai and Z. Zhang, "Microbial synthesis of semiconductor lead sulfide nanoparticles using immobilized Rhodobacter sphaeroides," Materials Letters, vol. 63, no. 9-10, pp. 764-766, 2009.

[134] J. T. Beveridge, M. N. Hughes, H. Lee et al., "Metal-microbe interactions: contemporary approaches," Advances in Microbial Physiology, vol. 38, pp. 178-243, 1997.

[135] D. A. Rouch, B. T. O. Lee, and A. P. Morby, "Understanding cellular responses to toxic agents: A model for mechanismchoice in bacterial metal resistance," Journal of Industrial Microbiology, vol. 14, no. 2, pp. 132-141, 1995.

[136] P. Mohanpuria, N. K. Rana, and S. K. Yadav, "Biosynthesis of nanoparticles: technological concepts and future applications," Journal of Nanoparticle Research, vol. 10, no. 3, pp. 507-517, 2008.

[137] P. Angell, "Understanding microbially influenced corrosion as biofilm-mediated changes in surface chemistry," Current Opinion in Biotechnology, vol. 10, no. 3, pp. 269-272, 1999.

[138] R. A. Zierenberg and P. Schiffman, "Microbial control of silver mineralization at a sea-floor hydrothermal site on the northern Gorda Ridge," Nature, vol. 348, no. 6297, pp. 155-157, 1990.

[139] P. I. Harvey and F. K. Crundwell, "Growth of Thiobacillus ferrooxidans: a novel experimental design for batch growth and bacterial leaching studies," Applied and Environmental Microbiology, vol. 63, no. 7, pp. 2586-2592, 1997.
[140] J. R. Stephen and S. J. Macnaughton, "Developments in terrestrial bacterial remediation of metals," Current Opinion in Biotechnology, vol. 10, no. 3, pp. 230-233, 1999.

[141] S. H. Kang, K. N. Bozhilov, N. V. Myung, A. Mulchandani, and W. Chen, "Microbial synthesis of CdS nanocrystals in genetically engineered E. coli," Angewandte Chemie-International Edition, vol. 47, no. 28, pp. 5186-5189, 2008.

[142] Y. Chen, H. Tuan, C. Tien, W. Lo, H. Liang, and Y. Hu, "Augmented biosynthesis of cadmium sulfide nanoparticles by genetically engineered Escherichia coli," Biotechnology Progress, vol. 25, no. 5, pp. 1260-1266, 2009.

[143] K. Kalishwaralal, S. Gopalram, R. Vaidyanathan, V. Deepak, S. R. K. Pandian, and S. Gurunathan, "Optimization of $\alpha$-amylase production for the green synthesis of gold nanoparticles," Colloids and Surfaces B: Biointerfaces, vol. 77, no. 2, pp. 174-180, 2010.

[144] T. J. Park, S. Y. Lee, N. S. Heo, and T. S. Seo, "In vivo synthesis of diverse metal nanoparticles by recombinant Escherichia coli," Angewandte Chemie-International Edition, vol. 49, no. 39, pp. 7019-7024, 2010.

[145] K. Deplanche, I. Caldelari, I. P. Mikheenko, F. Sargent, and L. E. Macaskie, "Involvement of hydrogenases in the formation of highly catalytic $\mathrm{Pd}(0)$ nanoparticles by bioreduction of $\mathrm{Pd}(\mathrm{II})$ using Escherichia coli mutant strains," Microbiology, vol. 156, no. 9, pp. 2630-2640, 2010.

[146] I. P. Mikheenko, M. Rousset, S. Dementin, and L. E. Macaskie, "Bioaccumulation of palladium by Desulfovibrio fructosivorans wild-type and hydrogenase-deficient strains," Applied and Environmental Microbiology, vol. 74, no. 19, pp. 6144-6146, 2008.

[147] M. F. Lengke and G. Southam, "The effect of thiosulfateoxidizing bacteria on the stability of the gold-thiosulfate complex," Geochimica et Cosmochimica Acta, vol. 69, no. 15, pp. 3759-3772, 2005.

[148] M. Lengke and G. Southam, "Bioaccumulation of gold by sulfate-reducing bacteria cultured in the presence of gold(I)thiosulfate complex," Geochimica et Cosmochimica Acta, vol. 70, no. 14, pp. 3646-3661, 2006.

[149] M. F. Lengke and G. Southam, "The deposition of elemental gold from gold(I)-thiosulfate complexes mediated by sulfatereducing bacterial conditions," Economic Geology, vol. 102, no. 1, pp. 109-126, 2007.

[150] C. A. Woolfolk and H. R. Whiteley, "Reduction of inorganic compounds with molecular hydrogen by Micrococcus lactilyticus. I. Stoichiometry with compounds of arsenic, selenium, tellurium, transition and other elements.", Journal of bacteriology, vol. 84, pp. 647-658, 1962.

[151] L. J. Yanke, R. D. Bryant, and E. J. Laishley, "Hydrogenase I of Clostridium pasteurianum functions as a novel selenite reductase," Anaerobe, vol. 1, no. 1, pp. 61-67, 1995.

[152] C. Michel, M. Brugna, C. Aubert, A. Bernadac, and M. Bruschi, "Enzymatic reduction of chromate: comparative studies using sulfate-reducing bacteria: key role of polyheme cytochromes c and hydrogenases," Applied Microbiology and Biotechnology, vol. 55, no. 1, pp. 95-100, 2001.

[153] O. A. Zadvorny, N. A. Zorin, and I. N. Gogotov, "Transformation of metals and metal ions by hydrogenases from phototrophic bacteria," Archives of Microbiology, vol. 184, no. 5, pp. 279-285, 2006.

[154] T. Matsunaga and H. Takeyama, "Biomagnetic nanoparticle formation and application," Supramolecular Science, vol. 5, no. 3-4, pp. 391-394, 1998. 
[155] D. Schüler, "Formation of magnetosomes in magnetotactic bacteria," Journal of Molecular Microbiology and Biotechnology, vol. 1, pp. 79-86, 1999.

[156] K. Grünberg, C. Wawer, B. M. Tebo, and D. Schüler, "A large gene cluster encoding several magnetosome proteins is conserved in different species of magnetotactic bacteria," Applied and Environmental Microbiology, vol. 67, no. 10, pp. 4573-4582, 2001.

[157] A. Arakaki, H. Nakazawa, M. Nemoto, T. Mori, and T. Matsunaga, "Formation of magnetite by bacteria and its application," Journal of the Royal Society Interface, vol. 5, no. 26, pp. 977-999, 2008.

[158] C. Moisescu, S. Bonneville, D. Tobler, I. Ardelean, and L. G. Benning, "Controlled biomineralization of magnetite $\left(\mathrm{Fe}_{3} \mathrm{O}_{4}\right)$ by Magnetospirillum gryphiswaldense," Mineralogical Magazine, vol. 72, no. 1, pp. 333-336, 2008.

[159] T. L. Riddin, Y. Govender, M. Gericke, and C. G. Whiteley, “Two different hydrogenase enzymes from sulphate-reducing bacteria are responsible for the bioreductive mechanism of platinum into nanoparticles," Enzyme and Microbial Technology, vol. 45, no. 4, pp. 267-273, 2009.

[160] J. W. Moreau, P. K. Weber, M. C. Martin, B. Gilbert, I. D. Hutcheon, and J. F. Banfield, "Extracellular proteins limit the dispersal of biogenic nanoparticles," Science, vol. 316, no. 5831, pp. 1600-1603, 2007.

[161] Y. Amemiya, A. Arakaki, S. S. Staniland, T. Tanaka, and T. Matsunaga, "Controlled formation of magnetite crystal by partial oxidation of ferrous hydroxide in the presence of recombinant magnetotactic bacterial protein Mms6," Biomaterials, vol. 28, no. 35, pp. 5381-5389, 2007.

[162] T. Prozorov, S. K. Mallapragada, B. Narasimhan et al., "Proteinmediated synthesis of uniform superparamagnetic magnetite nanocrystals," Advanced Functional Materials, vol. 17, no. 6, pp. 951-957, 2007.

[163] T. Prozorov, P. Palo, L. Wang et al., "Cobalt ferrite nanocrystals: out-performing magnetotactic bacteria," ACS Nano, vol. 1, no. 3, pp. 228-233, 2007.

[164] N. Mokhtari, S. Daneshpajouh, S. Seyedbagheri et al., "Biological synthesis of very small silver nanoparticles by culture supernatant of Klebsiella pneumonia: the effects of visible-light irradiation and the liquid mixing process," Materials Research Bulletin, vol. 44, no. 6, pp. 1415-1421, 2009.

[165] S. Iravani, H. Korbekandi, S. V. Mirmohammadi, and B. Zolfaghari, "Synthesis of silver nanoparticles: chemical, physical, and biological methods," Research in Pharmaceutical Sciences, vol. 9, pp. 385-406, 2014.

[166] S. S. Shankar, A. Rai, A. Ahmad, and M. Sastry, "Rapid synthesis of $\mathrm{Au}, \mathrm{Ag}$, and bimetallic Au core-Ag shell nanoparticles using Neem (Azadirachta indica) leaf broth," Journal of Colloid and Interface Science, vol. 275, no. 2, pp. 496-502, 2004. 

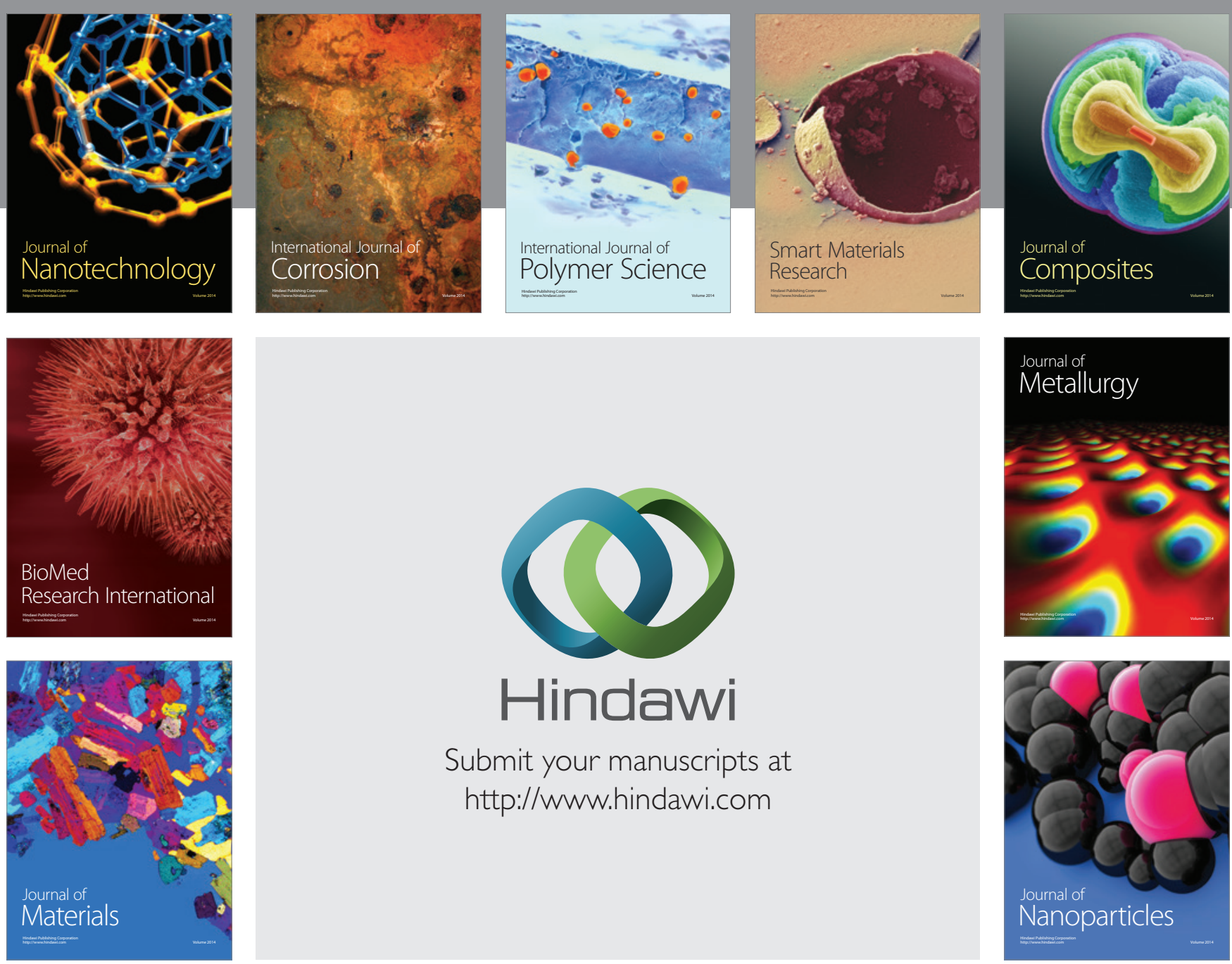

Submit your manuscripts at http://www.hindawi.com
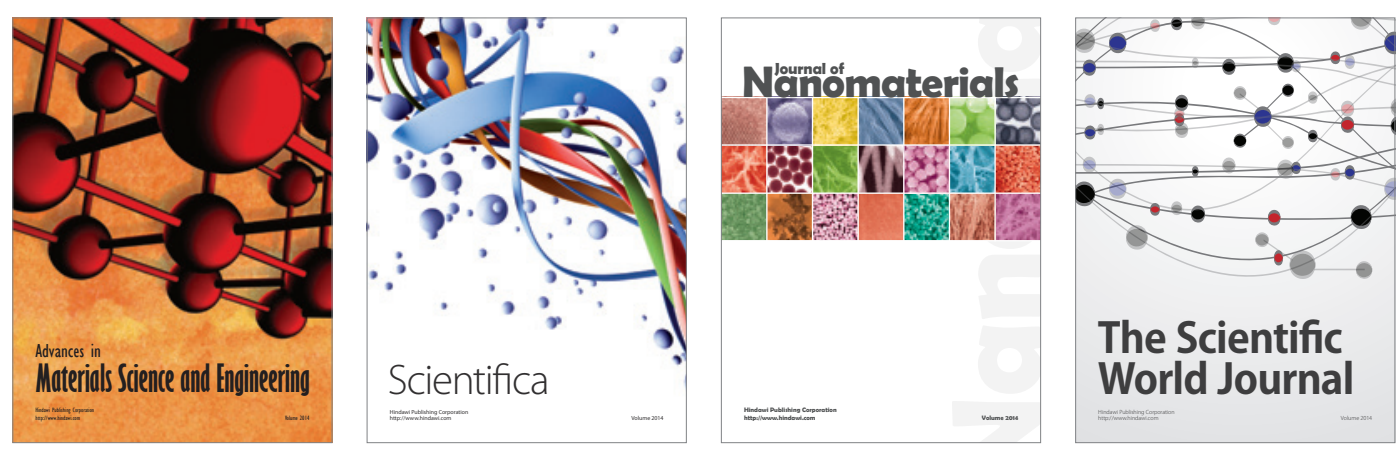

\section{The Scientific World Journal}
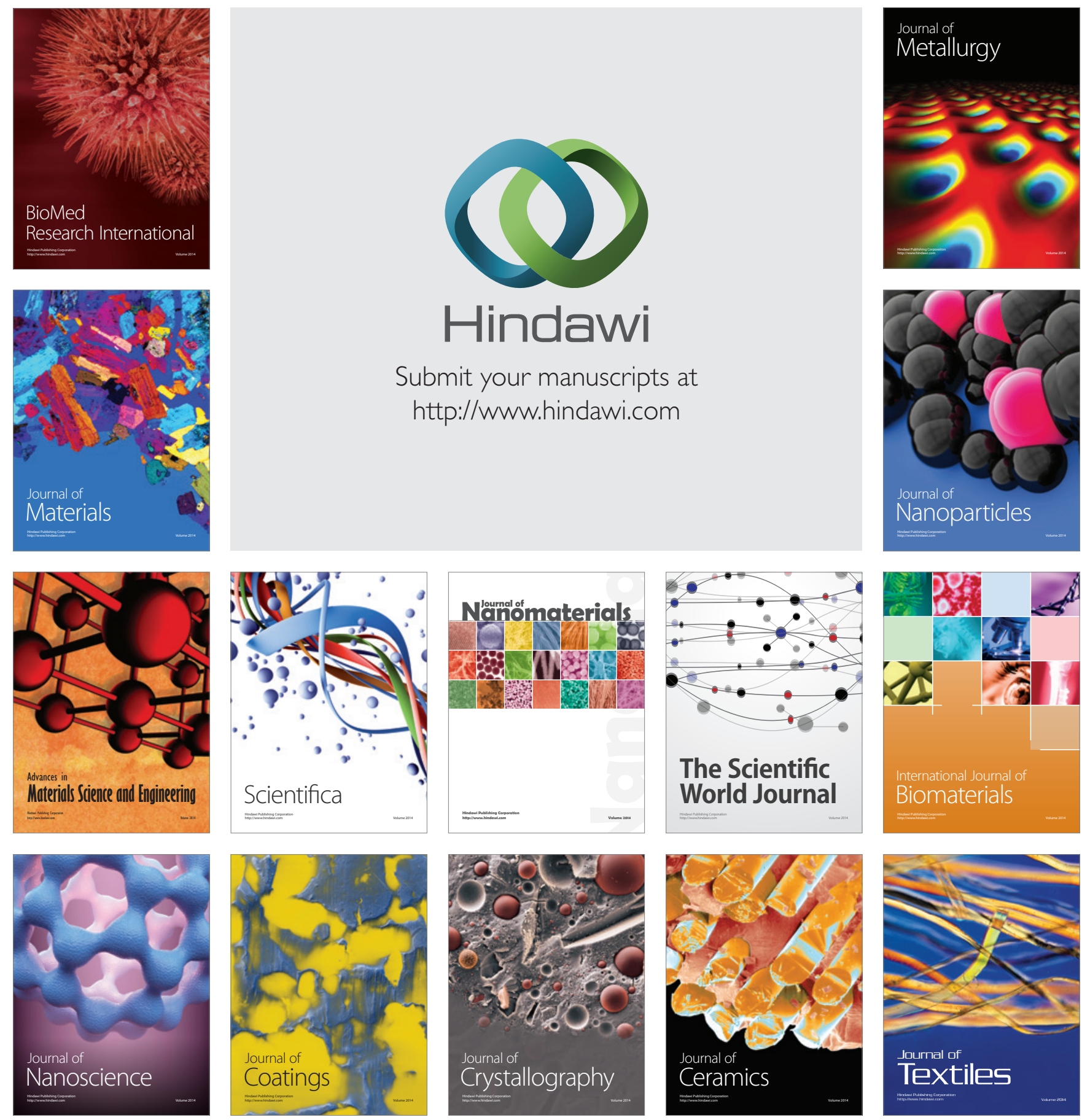